\title{
Management of rheumatoid arthritis: 2019 updated consensus recommendations from the Hong Kong Society of Rheumatology
}

\author{
Carmen Tze Kwan Ho ${ }^{1}$. Chi Chiu Mok ${ }^{2}$ (D) Tommy Tsang Cheung ${ }^{1} \cdot$ Kitty Yan Kwok ${ }^{3} \cdot$ Ronald Man Lung Yip ${ }^{4}$ for the \\ Hong Kong Society of Rheumatology
}

Received: 25 July 2019 / Revised: 16 August 2019 / Accepted: 20 August 2019 / Published online: 4 September 2019

(C) The Author(s) 2019

\begin{abstract}
The expanding range of treatment options for rheumatoid arthritis (RA), from conventional synthetic disease-modifying antirheumatic drugs (DMARDs) to biological DMARDs (bDMARDs), biosimilar bDMARDs, and targeted synthetic DMARDs, has improved patient outcomes but increased the complexity of treatment decisions. These updated consensus recommendations from the Hong Kong Society of Rheumatology provide guidance on the management of RA, with a focus on how to integrate newly available DMARDs into clinical practice. The recommendations were developed based on evidence from the literature along with local expert opinion. Early diagnosis of RA and prompt initiation of effective therapy remain crucial and we suggest a treat-to-target approach to guide optimal sequencing of DMARDs in RA patients to achieve tight disease control. Newly available DMARDs are incorporated in the treatment algorithm, resulting in a greater range of second-line treatment options. In the event of treatment failure or intolerance, switching to another DMARD with a similar or different mode of action may be considered. Given the variety of available treatments and the heterogeneity of patients with RA, treatment decisions should be tailored to the individual patient taking into consideration prognostic factors, medical comorbidities, drug safety, cost of treatment, and patient preference.
\end{abstract}

Keywords Consensus · DMARDs · Guideline · Management $\cdot$ Rheumatoid arthritis

\section{Introduction}

Rheumatoid arthritis (RA) is a chronic, autoimmune, inflammatory disease that may cause progressive joint damage and deformity, leading to functional disability and reduced quality of life $[1,2]$. The chronic inflammatory state of RA is also associated with extra-articular problems and increased

Carmen Tze Kwan Ho and Chi Chiu Mok are co-first authors

Chi Chiu Mok

ccmok2005@yahoo.com

1 Queen Mary Hospital, Pokfulam, Hong Kong

2 Department of Medicine, Tuen Mun Hospital, Tuen Mun, Hong Kong, China

3 Queen Elizabeth Hospital, Yau Ma Tei, Hong Kong

4 Hong Kong Society of Rheumatology, Tung Chau Street, Kowloon, Hong Kong mortality [1]. Compared with the age- and gender-matched population, a $68 \%$ increase in mortality risk has been reported in patients with RA in Hong Kong [3]. RA may be slightly less prevalent in Hong Kong than in Western countries [4, 5], where it affects approximately 0.5 to $1 \%$ of the population [6], but it is still associated with a considerable societal economic burden due to lost productivity and increased use of healthcare resources [7].

Over the last one to two decades, modern therapeutic strategies involving the early diagnosis of RA, the treatto-target principle, and disease-modifying antirheumatic drugs (DMARDs), which can prevent or reduce progression of structural joint damage and reduce mortality risk, have greatly improved the management of RA $[6,8,9]$. In addition to conventional synthetic DMARDs (csDMARDs), a range of biological DMARDs (bDMARDs) and, more recently, the first biosimilar bDMARDs and targeted synthetic DMARDs (tsDMARDs) are now available for the treatment of RA $[6,10]$. While b/tsDMARDs improve outcomes in many RA patients, they are costly and should be used in 
an evidence-based manner that accounts for availability and affordability within the local healthcare system $[6,9,11]$.

As a result of rising standards of care and the availability of more therapeutic options, RA treatment is becoming increasingly complex, and recommendations developed by professional societies are increasingly important for providing rheumatologists with evidence-based guidance on best-practice treatment approaches for their patients [9, 10, 12]. Updated recommendations from the European League Against Rheumatism (EULAR) and the Asian Pacific League of Associations for Rheumatology (APLAR) for the management of RA with DMARDs have recently been published $[10,12]$. Given the advances in RA management that have been made since our last set of recommendations were published in 2011 [9], we have now updated the Hong Kong Society of Rheumatology (HKSR) recommendations for the management of RA, with a focus on how best to integrate newly available DMARDs into Hong Kong clinical practice.

\section{Methods}

\section{Steering committee}

Members of the Rheumatoid Arthritis Special Interest Group (RA SIG) formulated a series of statements on RA management relevant to local Hong Kong practice and the healthcare system during several face-to-face meetings. Along with local expert opinions, the recently updated EULAR recommendations [10] were used to guide development of statements related to the use of DMARDs and glucocorticoids (GCs) in RA. In addition, the RA SIG formulated a series of statements related to treatment considerations for special populations, including pregnant women, those with chronic viral hepatitis infection, and patients seronegative for anti-citrullinated protein antibody (ACPA). The appropriate use of musculoskeletal ultrasound (MSUS) in the management of RA was also discussed.

\section{Grading evidence}

A system adapted from the Grades of Recommendations Assessment, Development and Evaluation (GRADE) system was used to rate the strength of the recommendation (SoR) and the quality of evidence (QoE) (Table 1) [13]. GRADE methodology gives preference to randomized controlled trials (RCTs) over observational studies as the highest quality source of evidence.

\section{Assessment of recommendation statements}

Practicing rheumatologists registered as full members of the HKSR were invited to join a roundtable meeting to discuss and finalize the consensus statements. The attendance rate was
$35 \%$. The series of statements was sent to all practicing rheumatologists of the HKSR for voting through several rounds of Delphi exercises. For each statement, rheumatologists voted agree or disagree using an anonymous electronic survey tool; if they voted "disagree," the reason for disagreement was required. The overall response rate was $55 \%$ (33 of 60 surveys; 7 surveys undeliverable).

For each statement, consensus was reached if $>80 \%$ of participating rheumatologists who responded to the survey voted "agree." If consensus was not reached for any statement, the statement was revised by the expert committee and recirculated for further voting until consensus was reached.

\section{Results}

The consensus process resulted in 36 recommendations: 33 statements reached consensus in the first round of voting and 3 statements reached consensus in the second round of voting. The recommendation statements are grouped into relevant categories and summarized in Table 2.

\section{Core principles}

The HKSR has included several core principles to serve as a foundation for more specific recommendations for RA management. Although there is no high-quality evidence to specifically support these, they are nevertheless strong recommendations with $>90 \%$ support from our rheumatologists.

1. Rheumatologists are the specialists who should primarily take care of patients with $R A$.

SoR: A; QoE: D

This acknowledges the importance of specialty care for a complex disease like RA [10]. Rapid assessment of patients by a rheumatologist soon after symptom onset enables rapid diagnosis and initiation of DMARD treatment, and improves outcomes [14-17]. General practitioners should refer patients with suspected RA to a rheumatologist and share their ongoing care with a rheumatologist and other specialists for the management of comorbidities (e.g., interstitial lung disease, inflammatory eye conditions, viral hepatitis, etc.) $[10,18,19]$. Patients in remission or with low and stable disease activity are candidates for shared care arrangements between rheumatologists, including nurse specialists, and primary care practitioners [19-21]. It is important for primary care physicians to have a working knowledge of RA and its treatment [22, 23].

2. Treatment of $R A$ should be based on a shared decision between the patient and the rheumatologist.

SoR: A; QoE: D

Shared decision-making is important for the success of 
Table 1 Grading system used to rate the strength of the recommendations and quality of supporting evidence

\begin{tabular}{|c|c|c|}
\hline Grade & Level & Meaning \\
\hline \multicolumn{3}{|c|}{ Strength of recommendation } \\
\hline A & Strong & $\begin{array}{l}\text { Most well-informed people would want the recommended } \\
\text { course of action, and none or only a small proportion would not. }\end{array}$ \\
\hline B & Weak & $\begin{array}{l}\text { The majority of well-informed people would want the recommended } \\
\text { course of action, but a substantial minority would not. }\end{array}$ \\
\hline \multicolumn{3}{|c|}{ Quality of evidence } \\
\hline A & High & We are very confident that the true effect lies close to that of the estimate of the effect. \\
\hline B & Moderate & $\begin{array}{l}\text { We are moderately confident in the effect estimate: the true effect is likely } \\
\text { to be close to the estimate of the effect, but there is a possibility that it is substantially different. }\end{array}$ \\
\hline $\mathrm{C}$ & Low & $\begin{array}{l}\text { Our confidence in the effect estimate is limited: the true effect may be substantially } \\
\text { different from the estimate of the effect. }\end{array}$ \\
\hline $\mathrm{D}$ & Very low & $\begin{array}{l}\text { We have very little confidence in the effect estimate: the true effect is likely to be } \\
\text { substantially different from the estimate of effect. }\end{array}$ \\
\hline
\end{tabular}

Based on the Grades of Recommendations Assessment, Development (GRADE) system [13]

treat-to-target strategies in RA [24]. Patients should be informed on all aspects of RA and its management, including the risks and benefits of individual treatments, and be involved in the development of a treatment plan to reach an agreed therapeutic target $[10,25]$. It is the responsibility of the rheumatologist to raise patients' awareness of their disease and treatment options [26, 27]. A mutually agreed treatment plan between the rheumatologist and patient facilitates treatment adherence [10].

3. Treatment choices should be individualized and based on a number offactors that include disease activity, prognostic factors, medical comorbidities, safety issues of the medications, cost, and availability of DMARDs.

SoR: A; QoE: D

Given the variety of available treatments and the heterogeneity of patients, management strategies should be tailored to the individual patient. In addition to factors such as disease activity, prognostic factors, medical comorbidities, and safety issues, it is specified that rheumatologists should also consider the cost and availability of newer b/tsDMARDs. Modification of DMARD therapy in terms of drug dosage, frequency of administration, and choice of drugs is needed in various clinical situations that include older age, impairment of renal, liver or cardiac function, other medical comorbidities, concomitant medications, history of intolerance, and complications to DMARDs, as well as other contraindications to a particular class of b/tsDMARDs.

\section{General statements on the treatment strategy for RA}

These recommendations cover general decisions that need to be made at the beginning of the management process once the diagnosis of RA has been made. All statements in this category are strong recommendations based on high-quality evidence.

4. Therapy with DMARDs should be started as soon as the diagnosis of RA is made.

\section{SoR: A; QoE: A}

Compared with delayed therapy, the short- and long-term beneficial effects of early DMARD therapy on the progression of radiographic joint damage and other outcomes are now well established [15, 28-32]. Early effective DMARD therapy initiated promptly after diagnosis is therefore important to preserve the structural and functional integrity of the joints [6, 33, 34]. The recommended sequence of DMARD types is included in the next group of recommendations, which address specific aspects of treatment.

5. Treatment should be targeted at sustained remission or low disease activity (if remission is not achievable).

SoR: A; QoE: A

Several studies have demonstrated that a targeted approach to the management of RA is superior to nontargeted approaches [35-39]. The best treatment goal is clinical remission, but this may be most appropriate in DMARD-naive patients [10, 40-42]. An acceptable alternative treatment target is low disease activity, which may be more appropriate in patients with long-standing disease who have failed previous therapies [10]. It has been cautioned that in certain situations, such as patients whose jobs involve physical labor that may aggravate the signs and symptoms of RA, remission or low disease activity may not be possible, and the treatment target may be to maintain symptom control and work ability [22]. 
Table 2 HKSR recommendations for the management of RA

Recommendations

SoR

QoE

Agreement (\%)

Core principles

1. Rheumatologists are the specialists who should primarily take care of patients with RA.

rheumatologist.

3. Treatment choices should be individualized and based on a number of factors that include disease activity, prognostic factors, medical comorbidities, safety issues of the medications, cost, and availability of DMARDs.

General statements on the treatment strategy of RA

4. Therapy with DMARDs should be started as soon as the diagnosis of RA is made.

5. Treatment should be targeted at sustained remission or low disease activity (if remission is not achievable).

6. Objective assessment of disease activity of RA should be obtained to guide treatment decision by means of at least one validated disease activity index (e.g., DAS28, CDAI, SDAI).

Treatment of RA

7. MTX should be the first-line therapy unless contraindicated.

8. In patients with contraindications or early intolerance to MTX, leflunomide or sulfasalazine may be considered as initial csDMARD therapy.

9. Hydroxychloroquine should not be used as first-line therapy in RA unless in patients with palindromic rheumatism and without poor prognostic factors of RA.

10. Although b/tsDMARDs have been used as first-line therapy in treatment-naive RA in some research studies, this approach is not routinely recommended.

11. Short-term GCs may be considered when initiating or changing csDMARDs, in different dose regimens and routes of administration, but should be tapered as rapidly as clinically feasible (preferably to $\leq 7.5 \mathrm{mg} /$ day of prednisolone or equivalent in $<10$ weeks).

12. Short-term bridging GCs during csDMARD therapy should ideally be discontinued within 3-6 months.

13. If there is no clinical response to the first csDMARD in 3 months or the treatment target cannot be reached in 6 months, adjustment of DMARD therapy is indicated.

14. When the treatment target cannot be achieved with MTX or other csDMARDs, switching or a combination of csDMARD may be considered in the absence of poor prognostic factors of RA.

15. When the treatment target cannot be achieved with MTX or other csDMARDs, add-on of a b/tsDMARD may be considered in the presence of poor prognostic factors of RA.

16. tsDMARDs (e.g., JAK inhibitors) can be considered in phase 2 of RA treatment; however, the longer safety record of bDMARDs should not be overlooked.

17. Systemic GC as bridging therapy should be avoided when a new b/tsDMARD is initiated because of the increased risk of infection.

Use of b/tsDMARD monotherapy

18. b/tsDMARDs should be combined with a csDMARD. In patients who cannot use csDMARDs as co-medications, IL-6 inhibitors and JAK inhibitors may have some advantages.

Switching b/tsDMARDs

19. If a bDMARD has failed, switching to another bDMARD or tsDMARD can be considered.

20. If a first TNF inhibitor has failed, another TNF inhibitor or a b/tsDMARD with another mode of action may be considered.

21. If an IL-6 inhibitor has failed, switching to another IL-6 inhibitor may be considered.

22. If a JAK inhibitor has failed, switching to another JAK inhibitor or other bDMARD may be considered.

Use of MSUS in the management of RA

23. Use MSUS to evaluate synovitis for diagnosing RA when clinical examination is inconclusive and inconsistent with laboratory tests.

24. Use MSUS to evaluate disease activity when clinical examination is inconclusive and inconsistent with other signs of disease activity (pain or inflammatory markers).

25. MSUS should not be used as routine evaluation of RA disease activity.

Role of biosimilar DMARDs

26. Approved biosimilars can be considered as an alternative to the bio-originators, particularly in biologic naive patients.
A

A

A

$\mathrm{D}$

94

97

A

D

A

A

100

A

A

100

A

A

100

A

B

97

A

A

94

A

B

91

A

B

97

A

A

97

A

D

94

A

C

88

A

B

A

B

B

A

A

96

94

A

A

A

A

A

D

100

B

D 
Table 2 (continued)

\begin{tabular}{|c|c|c|c|}
\hline Recommendations & SoR & QoE & Agreement $(\%)$ \\
\hline 27. Switching from bio-originator to biosimilars is acceptable. & $\mathrm{B}$ & $\mathrm{C}$ & 94 \\
\hline \multicolumn{4}{|l|}{ Tapering of bDMARD or csDMARD } \\
\hline 28. In sustained remission over 6 months, bDMARDs can be tapered in early RA. & A & $\mathrm{B}$ & 94 \\
\hline $\begin{array}{l}\text { 29. In sustained remission, cautious tapering of bDMARDs may be considered in } \\
\text { established RA due to an increased risk of flare. }\end{array}$ & $\mathrm{B}$ & $\mathrm{B}$ & 94 \\
\hline 30. After discontinuation of b/tsDMARDs, tapering of csDMARDs can be considered. & $\mathrm{B}$ & $\mathrm{D}$ & 94 \\
\hline \multicolumn{4}{|l|}{ Treatment consideration for seronegative RA } \\
\hline 31. Rituximab and abatacept are not preferred in patients with seronegative RA. & A & A & 97 \\
\hline \multicolumn{4}{|l|}{ Treatment considerations in pregnancy } \\
\hline 32. Use of TNF inhibitors is generally safe during first and second trimesters. & A & $\mathrm{C}$ & 97 \\
\hline $\begin{array}{l}\text { 33. Certolizumab and etanercept may be considered during the third trimester due to low } \\
\text { placental transfer. }\end{array}$ & A & $\mathrm{C}$ & 97 \\
\hline \multicolumn{4}{|l|}{ Treatment considerations in patients with chronic HBV and HCV infection } \\
\hline $\begin{array}{l}\text { 34. Prophylactic antiviral therapy should be prescribed for patients with chronic (HBsAg+ } \\
\text { ve) and occult (HBsAg-ve, Anti-HBc+ve, and HBV DNA+ve) HBV infection who } \\
\text { require b/tsDMARDs. }\end{array}$ & A & $\mathrm{C}$ & 82 \\
\hline $\begin{array}{l}\text { 35. Prophylactic antiviral therapy should not be prescribed for patients with resolved HBV } \\
\text { infection (HBsAg-ve, Anti-HBc+ve but HBV DNA-ve) EXCEPT when treated with B } \\
\text { cell depletion therapy. }\end{array}$ & A & $\mathrm{C}$ & 91 \\
\hline 36. b/tsDMARDs are not contraindicated in patients with chronic HCV infection. & A & D & 94 \\
\hline
\end{tabular}

Anti-HBc, antibody against HBV core antigen; bDMARD, biological DMARD; csDMARD, conventional synthetic DMARD; DMARD, diseasemodifying antirheumatic drug; $G C s$, glucocorticoids; $H B V$, hepatitis B virus; $H B s A G$, HBV surface antigen; $H C V$, hepatitis $\mathrm{C}$ virus; $I L$, interleukin; $J A K$, Janus kinase; MSUS, musculoskeletal ultrasound; MTX, methotrexate; RA, rheumatoid arthritis; QoE, quality of evidence; SoR, strength of recommendation; tsDMARD, targeted synthetic DMARD

6. Objective assessment of disease activity of RA should be obtained to guide treatment decision by means of at least one validated disease activity index (e.g., DAS28, CDAI, SDAI).

SoR: A; QoE: A

Validated composite measures, such as the disease activity score (DAS), clinical disease activity index (CDAI), or simplified disease activity index (SDAI), should be used to assess disease activity [10]. However, DAS-based remission, which has been widely used in clinical trials investigating a treat-totarget approach to RA [35, 36, 38], has been criticized as being potentially unreliable and less stringent than the CDAI or SDAI, and is probably better suited as a measure of low disease activity rather than remission [10, 41, 42].

\section{Treatment of RA}

The recommendations in this category relate to first-line and subsequent treatment strategies and therefore describe the preferred sequence of DMARDs (Fig. 1).

7. Methotrexate (MTX) should be the first-line therapy unless contraindicated.
SoR: A; QoE: B

Short-term, randomized, placebo-controlled trials, long-term prospective studies, and head-to-head trials comparing MTX with other csDMARDs have demonstrated the efficacy and acceptable safety profile of MTX in treatment-naive patients with RA [43, 44]. MTX monotherapy is well established as the first-line standard of care for patients with RA and MTX is considered the "anchor drug" for both monotherapy and combination therapy with other DMARDs (see recommendations 14 and 15 for advice on combination therapy) $[6,10,22$, 45].

8. In patients with contraindications or early intolerance to MTX, leflunomide or sulfasalazine may be considered as initial csDMARD therapy.

SoR: A; QoE: A

When required, the csDMARDs leflunomide or sulfasalazine are considered to be the best alternatives to MTX [10]. RCTs have shown the efficacy of these drugs to be superior to placebo and similar to that of MTX, although MTX was used at lower doses than those used currently [10, 46-52].

9. Hydroxychloroquine should not be used as first-line therapy in RA unless in patients with palindromic rheumatism and without poor prognostic factors of $R A$.

SoR: A; QoE: B 
There is some evidence that hydroxychloroquine has moderate efficacy in early RA [53, 54] and it is often used as monotherapy in patients with very mild disease [10]. There is also evidence suggesting that hydroxychloroquine may improve the metabolic profile and reduce cardiovascular risk in RA [55-57]. However, in view of its slow onset of action and the availability of more potent csDMARDs [58], we do not recommend hydroxychloroquine for the first-line treatment of RA in patients without contraindications to MTX.

10. Although b/tsDMARDs have been used as first-line therapy in treatment-naive $R A$ in some research studies, this approach is not routinely recommended.

SoR: A; QoE: B

The results of some recent RCTs have suggested that first-line monotherapy with certain b/tsDMARDs is more effective than MTX monotherapy and may be a viable option for patients with contraindications or intolerance to MTX (see recommendation 18) [59-64]. Importantly however, bridging with high-dose GCs was forbidden in the first 24 weeks of these trials, although low-dose pre-existing GCs were allowed (see recommendation 11) [10]. Moreover, evidence for firstline bDMARDs over first-line MTX plus GCs is inconsistent, with no clear advantages of early bDMARD therapy, other than a possible beneficial effect on long-term radiological outcome [10, 65-70]. Furthermore, evidence suggests that first-line therapy involving bDMARDs could lead to overtreatment of approximately $25 \%$ of patients at high cost $[6,71]$. There is also evidence to suggest that addition of a bDMARD in patients with suboptimal response to MTX monotherapy ultimately results in a similar response to initial combination therapy of the two agents [59, 72]. Taken together, there is currently insufficient convincing evidence to support a recommendation for the routine use of $b$ / tsDMARDS instead of, or in combination with, MTX as a first-line treatment strategy for RA, and there is no evidence supporting the cost-effectiveness of such an approach [6, 10].

11. Short-term GCs may be considered when initiating or changing csDMARDs, in different dose regimens and routes of administration, but should be tapered as rapidly as clinically feasible (preferably to $\leq 7.5 \mathrm{mg} /$ day of prednisolone or equivalent in $<10$ weeks).

SoR: A; QoE: A

The incremental efficacy of GCs when added to csDMARD therapy is well established, and given their rapid anti-inflammatory activity, GCs given orally, intravenously, or intramuscularly can be appropriate bridging therapy until the csDMARD reaches its full effect $[6,68$, 73-77]. Intra-articular or intra-tenosynovial GC administration can also be considered in certain circumstances
$[10,78]$. If daily oral GC dosing is used rather than a single intravenous or intramuscular dose, it should be quickly tapered to a low dose to avoid cumulative toxic effects $[6,79]$. According to the treatment protocols of recent RCTs, the dose of prednisone was tapered to $7.5 \mathrm{mg} /$ week in less than 10 weeks [75, 76, 80].

12. Short-term bridging GCs during csDMARD therapy should ideally be discontinued within 3-6 months.

SoR: A, QoE: D

GCs have been used for up to 6-12 months or longer in several RA treatment strategy studies [36, 37, 39, 81], and there are no RCTs comparing the duration of lowdose GCs as bridging therapy in RA. If GCs cannot be withdrawn within 3-6 months, it has been suggested that csDMARD therapy may have to be considered a failure [10]. Discontinuation of GCs within 3-6 months to avoid side effects is strongly recommended despite the lack of high-quality data on tapering and duration of treatment [81].

13. If there is no clinical response to the first csDMARD in 3 months or the treatment target cannot be reached in 6 months, adjustment of DMARD therapy is indicated.

SoR: A; QoE: C

In RCTs of RA treatment strategies, protocol-based assessment of disease activity was performed every 3 months to allow further adjustment of csDMARD therapy as needed $[35,37]$. No improvement in disease activity after 3 months of treatment made attainment of treatment target at 6 months highly unlikely [10, 82].

14. When the treatment target cannot be achieved with MTX or other csDMARDs, switching or a combination of csDMARDs may be considered in the absence of poor prognostic factors for $R A$.

SoR: A; QoE: B

Combination csDMARD therapy was included as an appropriate second-line treatment choice on the basis of the results of RCTs suggesting csDMARD combination therapy has superior efficacy to csDMARD monotherapy and is a more cost-effective option than bDMARDs [66, 83-92]. However, not all trials have shown such benefits [74, 93-96]. Therefore, a combination of csDMARDs should only be considered in patients who do not have poor prognostic factors for RA.

15. When the treatment target cannot be achieved with MTX or other cSDMARDs, adding on a b/tsDMARD may be considered in the presence of poor prognostic factors of $R A$.

SoR: A; QoE: B

This recommendation relates to the range of currently available b/tsDMARDs for the treatment of RA: the tumor necrosis factor (TNF) inhibitors adalimumab, certolizumab, etanercept, golimumab, and infliximab; the costimulation inhibitor abatacept; the interleukin 
(IL)-6 receptor inhibitors tocilizumab and sarilumab; the anti-B cell agent rituximab; and the Janus kinase (JAK) inhibitors (tsDMARDs) baricitinib and tofacitinib. RCTs have established that combination therapy with a b/ tsDMARD and a csDMARD is more effective than csDMARD monotherapy [11,93]. Although patients with poor prognostic factors were included in such studies, there are no subgroup analyses comparing outcomes in patients with and without poor prognostic factors. Overall, current evidence does not suggest superiority of csDMARD combination over certain bDMARDs in MTX failures in early RA, although bDMARDs offer better protection against radiological damage [66, 84, 85, 87, 89, 91, 92]. The choice between adding b/ tsDMARDs and a combination of csDMARDs according to the presence or absence of poor prognostic factors of RA is based on clinical decision [10]. As there is a paucity of head-to-head comparative RCTs, we do not include a preference of $\mathrm{b} / \mathrm{tsDMARDs}$ after MTX or csDMARD failures. Generally, bDMARDs have a longer track record for safety than tsDMARDs.

16. tsDMARDs (e.g., JAK inhibitors) can be considered in step 2 of RA treatment; however, the longer safety record of bDMARDs should not be overlooked.

SoR: B; QoE: A

Addition of a bDMARD or a tsDMARD to treatment is an effective and recommended treatment strategy in patients with an insufficient response to csDMARD therapy alone (see recommendation 15 above) [10]. There is, however, much more clinical experience with bDMARDs than with tsDMARDs, so in the absence of long-term safety data for tsDMARDs [93], bDMARDs may be preferred [6, 9, 10]. There is no preference for TNF inhibitor or non-TNF inhibitor bDMARDs [10]. The use of these agents is at the discretion of attending rheumatologists, who should consider costs, patient characteristics/comorbidities, contraindications to each bDMARD, and patient preference based on route and frequency of administration [9, 97].

17. Systemic GC as bridging therapy should be avoided when a new b/tsDMARD is initiated because of the increased risk of infection.

SoR: A; QoE: B

In contrast to csDMARDs, b/tsDMARDs have a rapid onset of action [10]. Several large observational cohort studies have shown that GCs are an independent risk factor for serious infection and related mortality in patients with RA receiving bDMARDs [98-100]. Therefore, bridging GCs should be reserved for csDMARD therapy only until the effect of the drugs is maximized (see recommendation 11) [10].

\section{Use of b/tsDMARD monotherapy}

18. b/tsDMARDs should be combined with a csDMARD. In patients who cannot use csDMARDs as co-medications, IL-6 inhibitors and JAK inhibitors may have some advantages.

SoR: A; QoE: A

The recommendation to use combination therapy reflects consistent RCT evidence that, relative to monotherapy, all b/tsDMARDs offer better efficacy when combined with a csDMARD $[10,11,93]$. A number of RCTs have demonstrated superiority of tocilizumab, tofacitinib, and baricitinib monotherapy over MTX monotherapy [59-64]. There is, however, no evidence that TNF inhibitor bDMARDs are clinically superior to MTX as monotherapy [10, 69]. As a result, IL-6 inhibitor or JAK inhibitor monotherapy may be preferred in patients who cannot use csDMARDs because of intolerance or contraindication [10]. Otherwise, b/tsDMARDs should be added to csDMARDs as combination therapy (see recommendations 10 and 15) [10].

\section{Switching b/tsDMARDs}

19. If a $b D M A R D$ has failed, switching to another $b D M A R D$ or tsDMARD can be considered.

SoR: A; QoE: A

This recommendation is based on meta-analyses showing that switching to another b/tsDMARD is effective in patients in whom previous bDMARD therapy failed [101, 102]. Prospective studies provide support for the use of a second bDMARD (abatacept, rituximab, or another TNF inhibitor) in patients previously unsuccessfully treated with a TNF inhibitor bDMARD [103, 104].

20. If a first TNF inhibitor has failed, another TNF inhibitor or a b/tsDMARD with another mode of action may be considered.

SoR: A; QoE: A

Although it may be expected that an agent with a different mode of action is needed in non-responders [6], RCTs show that use of another TNF inhibitor is effective in producing a clinical response [105-107]. Non-TNF inhibitor bDMARDs have also been shown to be effective in such patients [10, 101, 103-105, 108].

21. If an IL-6 inhibitor has failed, switching to another IL-6 inhibitor may be considered.

SoR: B; QoE: D

There is currently limited evidence to support inclass switching between IL-6 inhibitors [10, 109]. There is an abstract stating that a relevant proportion of tocilizumab non-responders showed clinical 


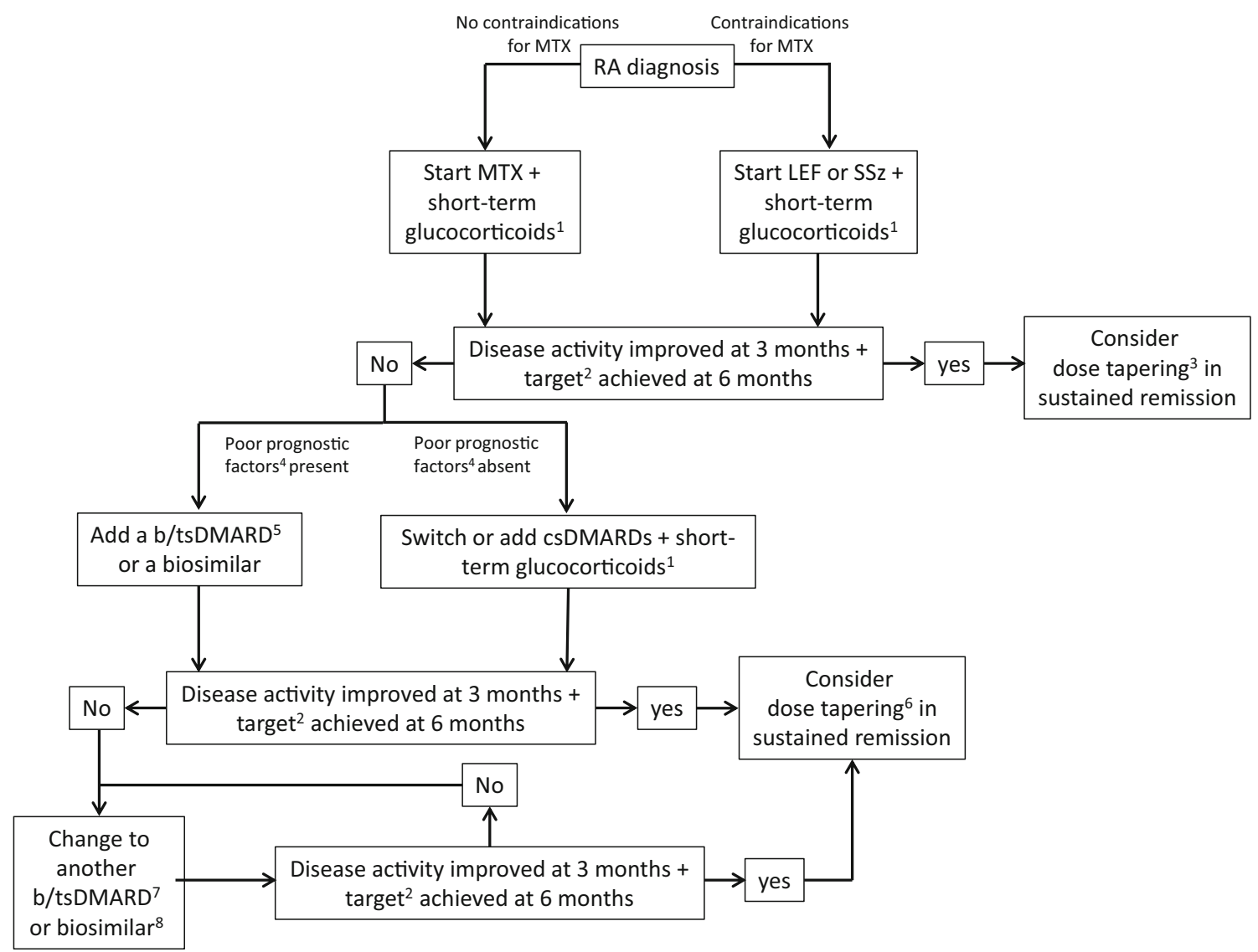

Fig. 1 Algorithm summarizing the 2019 HKSR recommendations for the treatment of patients with RA. ACPA, anticitrullinated protein antibody; bDMARD, biological DMARD; csDMARD, conventional synthetic DMARD; DMARD, disease-modifying antirheumatic drug; $I L$, interleukin; $L E F$, leflunomide; $M T X$, methotrexate; $R A$ rheumatoid arthritis; $R F$, rheumatoid factor; $S S z$, sulfasalazine; $T N F$, tumour necrosis factor; tsDMARD, targeted synthetic DMARD. ${ }^{1}$ Use glucocorticoids as bridging therapy with csDMARDs until the csDMARD reaches its full effect; ideally discontinue glucocorticoids within 3-6 months. ${ }^{2}$ The treatment target should be remission or low disease activity (if remission is not achievable). ${ }^{3}$ Generally dose reduction without complete withdrawal. ${ }^{4}$ Poor prognostic factors: moderate to high disease activity; high acute phase reactant levels; high swollen joint counts; presence of RF and/or ACPA, especially at high

improvement after switching to sarilumab despite low immunogenicity with tocilizumab [110]. There is no significant difference in adverse effects between tocilizumab and sarilumab use [111].

22. If a JAK inhibitor has failed, switching to another JAK inhibitor or other bDMARD may be considered.

SoR: B; QoE: D

JAK inhibitors have been studied in large RCTs of csDMARD non-responders and bDMARD non-responders. However, there is a paucity of studies on switching from JAK inhibitor non-responders to a second JAK inhibitor or to bDMARDs. This area is worth exploring as there is an increasing trend to use JAK inhibitors in step 2 of RA treatment. levels; presence of early erosions; failure of $\geq 2$ csDMARDs. ${ }^{5}$ Current practice would be to start with a bDMARD rather than a tsDMARD because of the longer safety record with bDMARDs; in patients who cannot use concomitant csDMARDs, IL-6 inhibitors and tsDMARDs (JAK-inhibitors) may have some advantages. ${ }^{6}$ Dose reduction or interval increase can be performed safely with low risk of flare, particularly in patients with early RA, but stopping is associated with high flare rates. ${ }^{7}$ This may be a bDMARD with the same or another mode of action, but if a second TNF-inhibitor fails, patients should receive an agent with another mechanism of action. ${ }^{8} \mathrm{~A}$ biosimilar of a bio-originator DMARD should not be used if there has been an insufficient response to the bio-originator (or another biosimilar of the same molecule) or vice versa

\section{Use of MSUS in the management of RA}

23. Use MSUS to evaluate synovitis for diagnosing RA when clinical examination is inconclusive and inconsistent with laboratory tests.

SoR: A; QoE: B

Gray-scale MSUS and power Doppler are validated for the identification of synovitis in RA. The combined gray-scale and power Doppler are validated for histological synovitis [112-114]. Observational studies have shown MSUS to be more effective than clinical examination for the detection of synovitis [114-118]. When there is diagnostic doubt, MSUS has been recommended to improve the certainty of a diagnosis of RA above 
clinical criteria alone due to its effectiveness in detecting subclinical synovitis [119, 120].

24. Use MSUS to evaluate disease activity when clinical examination is inconclusive and inconsistent with other signs of disease activity (pain or inflammatory markers).

SoR: A; QoE: A

There is no reliable evidence to justify routine use of MSUS in the assessment of disease activity in addition to composite disease activity scores [121-123]. However, when there is inconsistency between clinical examination and disease activity, it may be unclear if the patient has subclinical inflammatory synovitis or a more widespread pain syndrome, which may not be inflammatory. As treatment is different, it is important to differentiate these accurately by MSUS.

25. MSUS should not be used as a routine evaluation of RA disease activity.

SoR: A; QoE: A

Compared to clinical examination, ultrasound examination is a sensitive tool to detect residual synovial hypertrophy and power Doppler signal. Applying ultrasound may reclassify patients from clinical remission to low disease activity. However, there is insufficient evidence to support MSUS as a cost-effective component of routine disease monitoring during treat-to-target therapy [121-123].

\section{Role of biosimilar DMARDs}

26. Approved biosimilars can be considered as an alternative to the bio-originators, particularly in biologic naive patients.

SoR: A; QoE: A

Before each biosimilar is approved, regulatory agencies, such as the European Medicines Agency (EMA) and US Food and Drug Administration (FDA), require a pharmacokinetic/pharmacodynamic study in humans, and at least one RCT to demonstrate equivalent efficacy and immunogenicity and comparable safety of the biosimilar to its bio-originator. Compared with their respective bio-originator bDMARDs, equivalent efficacy and safety of several biosimilars targeting TNF have been observed in bDMARD-naive patients with RA in small-scale RCTs [124-128]. Biosimilars can be used as an alternative when cost is a consideration.

27. Switching from bio-originator to biosimilars is acceptable.

SoR: B; QoE: C

Observational extension studies of RCTs of biooriginator versus biosimilar products, in which RA patients initially treated with the bio-originator were switched to the biosimilar, have demonstrated no loss of efficacy or increase in the rate of adverse events after the switch [129-134]. Patients with RA were included in a RCT demonstrating that switching from bio-originator infliximab to biosimilar was non-inferior to continued treatment with the bio-originator in patients with immune-mediated inflammatory diseases, but the study was not powered to demonstrate non-inferiority of the switch for separate indications [135]. Real-world registry data also support the practice of switching patients with stable disease activity from bio-originator to biosimilar bDMARDs [136]. Although adequate evidence exists to support a switch from a bio-originator bDMARD to its biosimilar, there is currently no evidence to support switching between two biosimilars or between a biooriginator and its biosimilar on multiple occasions [137].

\section{Tapering of bDMARD or csDMARD}

28. In sustained remission over 6 months, bDMARDs can be tapered in early RA.

SoR: A; QoE: B

The feasibility of bDMARD tapering has been demonstrated in RCTs in patients with early RA who attained remission or low disease activity while receiving bDMARD therapy, and were randomized to continue full-dose bDMARD therapy or to a dose reduction strategy [72, 138, 139]. Analyses of subsets of patients from RCTs, who reached remission after randomization to receive bDMARD therapy and then underwent tapering of bDMARD, have also helped to establish the role of bDMARD tapering in early RA [67, 68, 140-143]. Collectively, the evidence suggests that patients with early RA in sustained remission (i.e., DAS $28<2.6$ for 6-12 months) during therapy with MTX and a bDMARD are the best candidates for bDMARD tapering (50\% dose reduction or discontinuation), and backbone csDMARD therapy should be continued. Continued careful monitoring is essential during and after tapering as flares can occur. Currently, most of the evidence supporting this recommendation relates to TNF inhibitor bDMARDs.

29. In sustained remission, cautious tapering of bDMARDs may be considered in established RA due to an increased risk of flare.

SoR: B; QoE: B

RCTs have been conducted in patients with established RA who were in remission or had low disease activity while receiving bDMARD therapy and were then randomized to continue full-dose bDMARD therapy or to a dose reduction strategy [144-148]. Compared with studies in patients with early RA (see recommendation 28), the results of these RCTs and 
prospective uncontrolled studies of bDMARD tapering in patients with established RA [149-158] show that tapering bDMARDs is feasible only in a relatively small subset of patients in sustained remission [159]. Several studies have shown that the detection of power Doppler signal on MSUS is predictive of a greater risk of flare after bDMARD tapering in patients with established RA previously in sustained DAS28 remission [160-162]. A combination of clinical and imaging remission could therefore potentially help to identify patients who are most likely to tolerate bDMARD tapering without flare, but further studies are required to confirm the costeffectiveness of such an approach [123, 159].

30. After discontinuation of b/tsDMARDs, tapering of csDMARDs can be considered.

SoR: B; QoE: D

Most recent studies have focused on tapering bDMARDs only [163,164] and evidence of csDMARD tapering is relatively weak. Two landmark RCTs conducted over two decades ago addressed the possibility of tapering csDMARDs in RA $[165,166]$. Tapering of csDMARDs has also been recently investigated in patients with early RA and sustained response, who had been treated in a treat-to-target manner after initial randomization to triple csDMARD therapy or MTX monotherapy [163]. It is generally thought that csDMARD tapering should entail cautious dose reduction without complete withdrawal [10, 12].

\section{Treatment consideration for seronegative RA}

31. Rituximab and abatacept are not preferred in patients with seronegative $R A$.

SoR: A; QoE: A

Both rituximab and abatacept have been shown to be most beneficial in patients with positive ACPA $[167,168]$.

\section{Treatment considerations in pregnancy}

32. Use of TNF inhibitors is generally safe during first and second trimesters.

SoR: A; QoE: C

Available data indicate that TNF inhibitors, which are classified as pregnancy category B (no documented human toxicity) by the US FDA, do not increase the risk of miscarriage or congenital malformation [169, 170]. Transport of immunoglobulin (IgG) proteins across the placenta increases steadily after the first trimester of pregnancy, and neonatal exposure to TNF inhibitor bDMARDs would be expected to be highest in infants of mothers exposed in the third trimester (see recommendation 33) [169]. Compared with the TNF inhibitor bDMARDs, rituximab, tocilizumab, and abatacept have comparatively limited documentation of safety in pregnancy and should be replaced by other medications before conception [169]. These drugs should be used during pregnancy only when no other pregnancycompatible drug can effectively control RA [169]. Since tsDMARDs have insufficient documentation for use in pregnancy, these should be avoided until further evidence is available [169].

33. Certolizumab and etanercept may be considered during the third trimester due to low placental transfer.

SoR: A; QoE: C

There is significant placental transfer of IgG during the third trimester, and as IgG clearance is relatively slow in neonates, prolonged exposure to TNF inhibitors during pregnancy may potentially increase the risk of neonatal infection [169, 171]. Among the TNF inhibitor bDMARDs, placental transfer of certolizumab and etanercept is relatively low, so these agents are preferred for use in the third trimester of pregnancy [169].

\section{Treatment considerations in patients with chronic hepatitis B virus and hepatitis C virus infection}

34. Prophylactic antiviral therapy should be prescribed for patients with chronic (HBsAg+ve) and occult (HBsAg-ve, Anti-HBc+ve, and $H B V D N A+v e$ ) $H B V$ infection who require b/tsDMARDs.

SoR: A; QoE: C

Clinical experience and case series show that the risk of hepatitis $B$ virus (HBV) reactivation with $b$ / tsDMARDs is substantially reduced when infected patients receive appropriate prophylactic antiviral therapy [45, 172]. In Asia, where HBV infection is endemic, screening for HBV should be conducted in all patients scheduled for b/tsDMARD therapy [22, 172]. For HBsAg+ve patients, prophylactic antiviral therapy should be started at least 1 week before the use of b/tsDMARDs [172]. There is a lack of evidence regarding the first-line choice of prophylactic antiviral drug, but either entecavir or tenofovir would be appropriate in patients with chronic HBV infection [172].

35. Prophylactic antiviral therapy should not be prescribed for patients with resolved hepatitis $B$ infection (HBsAg-ve, Anti-HBc+ve but $H B V$ DNA-ve) EXCEPT when treated with $B$ cell depletion therapy.

SoR: A; QoE: C

Case series show that for patients with resolved 
HBV infection treated with $b /$ tsDMARDs, the risk of reactivation with $b /$ tsDMARD therapy is very low [172]. Routine use of prophylactic antiviral therapy would therefore not be a cost-effective approach in these patients, but patients should be closely monitored for reactivation [172]. Antiviral prophylaxis may however be advisable in patients with resolved HBV infection scheduled for treatment with rituximab, which can induce profound $\mathrm{B}$ cell depletion resulting in secondary immunosuppression [172].

36. b/tsDMARDs are not contraindicated in patients with chronic HCV infection.

SoR: A; QoE: D

Small case series suggest that the use of TNF inhibitors does not affect viral load or cause reactivation of hepatitis C virus (HCV) [172-177]. However, there is a lack of safety data of tsDMARDs in patients with $\mathrm{HCV}$ infection. TNF inhibitor bDMARDs have the longest safety record; therefore, they are the preferred bDMARDs in patients with RA and chronic HCV. These patients should be warned of the risk of $\mathrm{HCV}$ reactivation and be monitored by hepatologists.

\section{Discussion}

Recommendations for the use of the newly available tsDMARDs and biosimilar DMARDS are an important feature of this updated consensus. Early diagnosis of RA and prompt initiation of DMARD therapy according to the treatto-target approach are crucial. Patients presenting with symptoms suggestive of RA should be referred to a rheumatologist for evaluation early before irreversible joint damage occurs [6, 10]. Early RA is characterized by synovitis [6], but it may be difficult to detect subclinical synovitis during physical examination [178]. ACPA and MSUS are valuable tools to aid early diagnosis of RA [179-181].

The treatment target of RA should be sustained remission or low disease activity when remission cannot be achieved. Frequent monitoring of disease activity (ideally every 3 months) and prompt adjustment of treatment if the target is not reached are the foundations of an effective treat-to-target approach [6]. A $\geq 50 \%$ clinical improvement in a validated composite disease activity measure is desirable within 3 months of a new treatment and the target should be achieved within 6 months [10, 82].

In line with our 2011 recommendations for first-line DMARD treatment of RA [5], the general consensus is still that patients should receive MTX monotherapy [10, 12, 45]. Despite the increasing evidence of the b/tsDMARDs in RA $[59,60,62-68,70,72,182]$, there remains insufficient evidence to support a recommendation for b/tsDMARDs as first-line therapy. We reiterate our previous general recommendation to use GC bridging therapy during csDMARD therapy [5], but we now also specify a low-dose target (i.e., $\leq 7.5 \mathrm{mg}$ /day of prednisolone within 10 weeks of starting a csDMARD) and that GCs should ideally be discontinued within 3-6 months. Such practices should help to minimize GC use and reduce their adverse effects.

While similar in principle to our 2011 recommendations for stepping up of DMARDs [5], our updated recommendations incorporate newly available tsDMARDs and biosimilar DMARDs in the treatment algorithm. When there is insufficient response to first-line csDMARD therapy, patients should be stratified according to prognostic factors. Patients without poor prognostic factors have the option of switching to another csDMARD as monotherapy, or receiving csDMARD combination therapy, whereas the addition of a b/tsDMARD to MTX should be considered in patients with poor prognostic factors. Although we do not provide specific statements on the risk of infection during b/tsDMARD therapy, any ongoing GC bridging therapy should be discontinued before starting a $\mathrm{b} / \mathrm{tsDMARD}$. It is prudent to protect against the most common vaccine-preventable infections in patients with RA, including Pneumococcus, influenza, HBV, human papilloma virus, and herpes zoster $[12,45]$. If the first b/tsDMARD fails, patients should be switched to another b/tsDMARD with the same or a different mode of action to the initial b/tsDMARD. In the event that two b/tsDMARDs with the same mode of action fail (i.e., two TNF inhibitor bDMARDs), a b/tsDMARD with a different mode of action should be considered [10].

While we specify that monotherapy with IL-6 inhibitors or JAK inhibitors may be preferable to other bDMARDs in patients who cannot tolerate csDMARDs, and that TNF inhibitor bDMARDs are the only b/tsDMARDs with sufficient safety data to justify their use during pregnancy, there is no hierarchical positioning for the use of any type of $b / t s D M A R D$ in combination with a csDMARD. As the efficacy of $b$ / tsDMARDs (TNF inhibitor bDMARDs, non-TNF inhibitor bDMARDs, and JAK inhibitors) does not differ, the initial choice of drugs should be based on patient preference, tolerability, and cost [10, 12, 69].

Although bDMARDs may be preferred to tsDMARDs for their longer track record [10], the latter have the potential to gain at least an equal footing to bDMARDs within the RA treatment algorithm when more long-term tsDMARD safety data become available.

In the event of sustained remission (>6 months) during combined csDMARD/bDMARD therapy, bDMARD tapering is feasible in a subset of patients - especially patients with early RA [159, 183]. The risk of flare may be lowered if the bDMARD dose is reduced rather than discontinued [164]. We therefore recommend a relatively cautious approach to tapering in patients with established RA, ideally without 
discontinuation of bDMARD therapy, because of an increased risk of flare. Patients who experience a disease flare after discontinuation of bDMARD therapy could regain remission with the resumption of the original bDMARD $[9,159]$.

In comparison to the EULAR recommendations, ours have incorporated the treatment consideration for special patient groups such as seronegative RA, pregnant patients, and those with chronic hepatitis $B$ and $C$ infection. The clinical application of musculoskeletal ultrasound, the use of biosimilars, and the switching between bio-originators and biosimilars are also included. Similar to other parts of the world, the health care system of Hong Kong is facing challenges that include rising costs, increasing demand for medical service, and more expensive technologies, as well as an aging population. The $\mathrm{b} /$ tsDMARDs are reimbursed by our Government in less effluent patients. Our updated consensus recommendations may serve as a guidance to the hospital administration for adjusting the subsidy scheme of the b/tsDMARDs in RA. We will continue to update and modify our recommendations periodically based on novel evidence in the literature.

Acknowledgments The authors acknowledge Weber Shandwick Hong Kong for editorial support in the preparation of this manuscript.

\section{Compliance with ethical standards}

\section{Disclosures None.}

Open Access This article is distributed under the terms of the Creative Commons Attribution 4.0 International License (http:// creativecommons.org/licenses/by/4.0/), which permits unrestricted use, distribution, and reproduction in any medium, provided you give appropriate credit to the original author(s) and the source, provide a link to the Creative Commons license, and indicate if changes were made.

\section{References}

1. Smolen JS, Aletaha D, McInnes IB (2016) Rheumatoid arthritis. Lancet Lond Engl 388:2023-2038. https://doi.org/10.1016/ S0140-6736(16)30173-8

2. Cutolo M, Kitas GD, van Riel PLCM (2014) Burden of disease in treated rheumatoid arthritis patients: going beyond the joint. Semin Arthritis Rheum 43:479-488. https://doi.org/10.1016/j. semarthrit.2013.08.004

3. Mok CC, Kwok CL, Ho LY, Chan PT, Yip SF (2011) Life expectancy, standardized mortality ratios, and causes of death in six rheumatic diseases in Hong Kong, China. Arthritis Rheum 63: 1182-1189. https://doi.org/10.1002/art.30277

4. Lau E, Symmons D, Bankhead C, MacGregor A, Donnan S, Silman A (1993) Low prevalence of rheumatoid arthritis in the urbanized Chinese of Hong Kong. J Rheumatol 20:1133-1137

5. Mok CC, Tam LS, Chan TH et al (2011) Management of rheumatoid arthritis: consensus recommendations from the Hong Kong Society of Rheumatology. Clin Rheumatol 30:303-312. https:// doi.org/10.1007/s10067-010-1596-y
6. Smolen JS, Aletaha D, Barton A, Burmester GR, Emery P, Firestein GS, Kavanaugh A, McInnes IB, Solomon DH, Strand V, Yamamoto K (2018) Rheumatoid arthritis. Nat Rev Dis Primer 4:18001. https://doi.org/10.1038/nrdp.2018.1

7. Zhu TY, Tam L-S, Li EK (2011) Societal costs of rheumatoid arthritis in Hong Kong: a prevalence-based cost-of-illness study. Rheumatol Oxf Engl 50:1293-1301. https://doi.org/10.1093/ rheumatology/ker014

8. Minichiello E, Semerano L, Boissier M-C (2016) Time trends in the incidence, prevalence, and severity of rheumatoid arthritis: a systematic literature review. Jt Bone Spine Rev Rhum 83:625630. https://doi.org/10.1016/j.jbspin.2016.07.007

9. Mok CC (2017) EULAR recommendations for the management of rheumatoid arthritis: what is new in 2017and its applicability in our local setting. Hong Kong Bull Rheum Dis 17:47-52. https:// doi.org/10.1515/hkbrd-2017-0009

10. Smolen JS, Landewé R, Bijlsma J, Burmester G, Chatzidionysiou K, Dougados M, Nam J, Ramiro S, Voshaar M, van Vollenhoven R, Aletaha D, Aringer M, Boers M, Buckley CD, Buttgereit F, Bykerk V, Cardiel M, Combe B, Cutolo M, van Eijk-Hustings Y, Emery P, Finckh A, Gabay C, Gomez-Reino J, Gossec L, Gottenberg JE, Hazes JMW, Huizinga T, Jani M, Karateev D, Kouloumas M, Kvien T, Li Z, Mariette X, McInnes I, Mysler E, Nash P, Pavelka K, Poór G, Richez C, van Riel P, Rubbert-Roth A, Saag K, da Silva J, Stamm T, Takeuchi T, Westhovens R, de Wit M, van der Heijde D (2017) EULAR recommendations for the management of rheumatoid arthritis with synthetic and biological disease-modifying antirheumatic drugs: 2016 update. Ann Rheum Dis 76:960-977. https://doi.org/10.1136/annrheumdis-2016210715

11. Nam JL, Takase-Minegishi K, Ramiro S, Chatzidionysiou K, Smolen JS, van der Heijde D, Bijlsma JW, Burmester GR, Dougados M, Scholte-Voshaar M, van Vollenhoven R, Landewé R (2017) Efficacy of biological disease-modifying antirheumatic drugs: a systematic literature review informing the 2016 update of the EULAR recommendations for the management of rheumatoid arthritis. Ann Rheum Dis 76:1113-1136. https://doi.org/10.1136/ annrheumdis-2016-210713

12. Lau CS, Chia F, Dans L et al (2019) 2018 update of the APLAR recommendations for treatment of rheumatoid arthritis. Int $\mathrm{J}$ Rheum Dis 22:357-375. https://doi.org/10.1111/1756-185X. 13513

13. Atkins D, Best D, Briss PA et al (2004) Grading quality of evidence and strength of recommendations. BMJ 328:1490. https:// doi.org/10.1136/bmj.328.7454.1490

14. Feldman DE, Bernatsky S, Houde M, Beauchamp ME, Abrahamowicz M (2013) Early consultation with a rheumatologist for RA: does it reduce subsequent use of orthopaedic surgery? Rheumatol Oxf Engl 52:452-459. https://doi.org/10.1093/ rheumatology/kes 231

15. Kyburz D, Gabay C, Michel BA, Finckh A, for the physicians of the SCQM-RA (2011) The long-term impact of early treatment of rheumatoid arthritis on radiographic progression: a populationbased cohort study. Rheumatol Oxf Engl 50:1106-1110. https:// doi.org/10.1093/rheumatology/keq424

16. Gärtner M, Fabrizii JP, Koban E, Holbik M, Machold LP, Smolen JS, Machold KP (2012) Immediate access rheumatology clinic: efficiency and outcomes. Ann Rheum Dis 71:363-368. https:// doi.org/10.1136/annrheumdis-2011-200315

17. Puchner R, Janetschko R, Kaiser W, Linkesch M, Steininger M, Tremetsberger R, Alkin A, Machold K (2016) Efficacy and outcome of rapid access rheumatology consultation: an office-based pilot cohort study. J Rheumatol 43:1130-1135. https://doi.org/10. 3899/jrheum. 151210

18. Memel DS, Somerset M (2003) General practitioner and specialist care: the perceptions of people with rheumatoid arthritis. Prim 
Health Care Res Dev 4:29-37. https://doi.org/10.1191/ $1463423603 \mathrm{pc} 120$ oa

19. Lythgoe MP, Abraham S (2016) Good practice in shared care for inflammatory arthritis. Br J Gen Pract J R Coll Gen Pract 66:275277. https://doi.org/10.3399/bjgp16X685177

20. Lion V, Schirmer M (2018) Nurses' roles in the management of chronic inflammatory arthritis: a systematic review. Rheumatol Int 38:2027-2036. https://doi.org/10.1007/s00296-018-4135-9

21. Primdahl J, Sørensen J, Horn HC, Petersen R, Hørslev-Petersen K (2014) Shared care or nursing consultations as an alternative to rheumatologist follow-up for rheumatoid arthritis outpatients with low disease activity — patient outcomes from a 2-year, randomised controlled trial. Ann Rheum Dis 73:357-364. https://doi.org/10. 1136/annrheumdis-2012-202695

22. Lau CS, Chia F, Harrison A, Hsieh TY, Jain R, Jung SM, Kishimoto M, Kumar A, Leong KP, Li Z, Lichauco JJ, Louthrenoo W, Luo SF, Nash P, Ng CT, Park SH, Suryana BP, Suwannalai P, Wijaya LK, Yamamoto K, Yang Y, Yeap SS, Asia Pacific League of Associations for Rheumatology (2015) APLAR rheumatoid arthritis treatment recommendations. Int J Rheum Dis 18:685-713. https://doi.org/10.1111/1756-185X.12754

23. Shiu W, Wong T, Chao DVK (2018) A review on the diagnosis and management of rheumatoid arthritis in general practice. Hong Kong Pract 40:61-72

24. Fraenkel L, Nowell WB, Michel G, Wiedmeyer C (2018) Preference phenotypes to facilitate shared decision-making in rheumatoid arthritis. Ann Rheum Dis 77:678-683. https://doi. org/10.1136/annrheumdis-2017-212407

25. Stoffer MA, Smolen JS, Woolf A, Ambrozic A, Bosworth A, Carmona L, Fialka-Moser V, Loza E, Olejnik P, Petersson IF, Uhlig T, Stamm TA, the eumusc.net-working group (2014) Development of patient-centred standards of care for rheumatoid arthritis in Europe: the eumusc.net project. Ann Rheum Dis 73: 902-905. https://doi.org/10.1136/annrheumdis-2013-203743

26. Mathews AL, Coleska A, Burns PB, Chung KC (2016) Evolution of patient decision-making regarding medical treatment of rheumatoid arthritis. Arthritis Care Res 68:318-324. https://doi.org/10. 1002/acr.22688

27. Nota I, Drossaert CHC, Taal E, van de Laar MAFJ (2016) Arthritis patients' motives for (not) wanting to be involved in medical decision-making and the factors that hinder or promote patient involvement. Clin Rheumatol 35:1225-1235. https://doi.org/10. 1007/s10067-014-2820-y

28. Egsmose C, Lund B, Borg G et al (1995) Patients with rheumatoid arthritis benefit from early 2 nd line therapy: 5 year followup of a prospective double blind placebo controlled study. J Rheumatol 22:2208-2213

29. Moura CS, Abrahamowicz M, Beauchamp M-E et al (2015) Early medication use in new-onset rheumatoid arthritis may delay joint replacement: results of a large population-based study. Arthritis Res Ther 17:197. https://doi.org/10.1186/s13075-015-0713-3

30. Tsakonas E, Fitzgerald AA, Fitzcharles MA, Cividino A, Thorne JC, M'Seffar A, Joseph L, Bombardier C, Esdaile JM (2000) Consequences of delayed therapy with second-line agents in rheumatoid arthritis: a 3 year followup on the hydroxychloroquine in early rheumatoid arthritis (HERA) study. J Rheumatol 27:623629

31. Möttönen T, Hannonen P, Korpela M, Nissilä M, Kautiainen H, Ilonen J, Laasonen L, Kaipiainen-Seppänen O, Franzen P, Helve T, Koski J, Gripenberg-Gahmberg M, Myllykangas-Luosujärvi R, Leirisalo-Repo M (2002) Delay to institution of therapy and induction of remission using single-drug or combination-diseasemodifying antirheumatic drug therapy in early rheumatoid arthritis. Arthritis Rheum 46:894-898

32. van Aken J, Lard LR, le Cessie S, Hazes JM, Breedveld FC, Huizinga TW (2004) Radiological outcome after four years of early versus delayed treatment strategy in patients with recent onset rheumatoid arthritis. Ann Rheum Dis 63:274-279. https:// doi.org/10.1136/ard.2003.010298

33. van Nies JAB, Krabben A, Schoones JW et al (2014) What is the evidence for the presence of a therapeutic window of opportunity in rheumatoid arthritis? A systematic literature review. Ann Rheum Dis 73:861-870. https://doi.org/10.1136/annrheumdis2012-203130

34. Widdifield J, Moura CS, Wang Y, Abrahamowicz M, Paterson JM, Huang A, Beauchamp ME, Boire G, Fortin PR, Bessette L, Bombardier C, Hanly JG, Feldman D, Bernatsky S, The CAnadian Network for Advanced Interdisciplinary Methods for comparative effectiveness research (CAN-AIM) (2016) The longterm effect of early intensive treatment of seniors with rheumatoid arthritis: a comparison of 2 population-based cohort studies on time to joint replacement surgery. J Rheumatol 43:861-868. https://doi.org/10.3899/jrheum. 151156

35. Goekoop-Ruiterman YPM, de Vries-Bouwstra JK, Kerstens PJSM, Nielen MMJ, Vos K, van Schaardenburg D, Speyer I, Seys PEH, Breedveld FC, Allaart CF, Dijkmans BAC (2010) DAS-driven therapy versus routine care in patients with recentonset active rheumatoid arthritis. Ann Rheum Dis 69:65-69. https://doi.org/10.1136/ard.2008.097683

36. Grigor C, Capell H, Stirling A, McMahon AD, Lock P, Vallance R, Porter D, Kincaid W (2004) Effect of a treatment strategy of tight control for rheumatoid arthritis (the TICORA study): a single-blind randomised controlled trial. Lancet Lond Engl 364: 263-269. https://doi.org/10.1016/S0140-6736(04)16676-2

37. van Eijk IC, Nielen MMJ, van der Horst-Bruinsma I, Tijhuis GJ, Boers M, Dijkmans BAC, van Schaardenburg D (2012) Aggressive therapy in patients with early arthritis results in similar outcome compared with conventional care: the STREAM randomized trial. Rheumatol Oxf Engl 51:686-694. https://doi.org/ 10.1093/rheumatology/ker355

38. Schipper LG, Vermeer M, Kuper HH, Hoekstra MO, Haagsma CJ, Broeder AAD, Riel P, Fransen J, van de Laar MAFJ (2012) A tight control treatment strategy aiming for remission in early rheumatoid arthritis is more effective than usual care treatment in daily clinical practice: a study of two cohorts in the Dutch Rheumatoid Arthritis Monitoring registry. Ann Rheum Dis 71:845-850. https://doi.org/10.1136/annrheumdis-2011-200274

39. Verstappen SMM, Jacobs JWG, van der Veen MJ, Heurkens AHM, Schenk Y, ter Borg EJ, Blaauw AAM, Bijlsma JWJ, on the behalf of the Utrecht Rheumatoid Arthritis Cohort study group (2007) Intensive treatment with methotrexate in early rheumatoid arthritis: aiming for remission. Computer Assisted Management in Early Rheumatoid Arthritis (CAMERA, an open-label strategy trial). Ann Rheum Dis 66:1443-1449. https://doi.org/10.1136/ ard.2007.071092

40. Radner H, Smolen JS, Aletaha D (2014) Remission in rheumatoid arthritis: benefit over low disease activity in patient-reported outcomes and costs. Arthritis Res Ther 16:R56. https://doi.org/10. $1186 /$ ar4491

41. Ruyssen-Witrand A, Guernec G, Nigon D, Tobon G, Jamard B, Rat AC, Vittecoq O, Cantagrel A, Constantin A (2015) Aiming for SDAI remission versus low disease activity at 1 year after inclusion in ESPOIR cohort is associated with better 3-year structural outcomes. Ann Rheum Dis 74:1676-1683. https://doi.org/10. 1136/annrheumdis-2013-204906

42. Smolen JS, Breedveld FC, Burmester GR, Bykerk V, Dougados M, Emery P, Kvien TK, Navarro-Compán MV, Oliver S, Schoels M, Scholte-Voshaar M, Stamm T, Stoffer M, Takeuchi T, Aletaha D, Andreu JL, Aringer M, Bergman M, Betteridge N, Bijlsma H, Burkhardt H, Cardiel M, Combe B, Durez P, Fonseca JE, Gibofsky A, Gomez-Reino JJ, Graninger W, Hannonen P, Haraoui B, Kouloumas M, Landewe R, Martin-Mola E, Nash P, 
Ostergaard M, Östör A, Richards P, Sokka-Isler T, Thorne C, Tzioufas AG, van Vollenhoven R, de Wit M, van der Heijde D (2016) Treating rheumatoid arthritis to target: 2014 update of the recommendations of an international task force. Ann Rheum Dis 75:3-15. https://doi.org/10.1136/annrheumdis-2015-207524

43. Weinblatt ME (1995) Efficacy of methotrexate in rheumatoid arthritis. Br J Rheumatol 34(Suppl 2):43-48

44. Weinblatt ME (2013) Methotrexate in rheumatoid arthritis: a quarter century of development. Trans Am Clin Climatol Assoc 124: $16-25$

45. Singh JA, Saag KG, Bridges SL et al (2016) 2015 American College of Rheumatology guideline for the treatment of rheumatoid arthritis. Arthritis Care Res 68:1-25. https://doi.org/10.1002/ acr. 22783

46. Dougados M, Combe B, Cantagrel A, Goupille P, Olive P, Schattenkirchner M, Meusser S, Paimela L, Rau R, Zeidler H, Leirisalo-Repo M, Peldan K (1999) Combination therapy in early rheumatoid arthritis: a randomised, controlled, double blind 52 week clinical trial of sulphasalazine and methotrexate compared with the single components. Ann Rheum Dis 58:220-225. https:// doi.org/10.1136/ard.58.4.220

47. Emery P, Breedveld FC, Lemmel EM, Kaltwasser JP, Dawes PT, Gömör B, van den Bosch F, Nordström D, Bjørneboe O, Dahl R, Hørslev-Petersen K, Rodriguez de la Serna A, Molloy M, Tikly M, Oed C, Rosenburg R, Loew-Friedrich I (2000) A comparison of the efficacy and safety of leflunomide and methotrexate for the treatment of rheumatoid arthritis. Rheumatol Oxf Engl 39:655665. https://doi.org/10.1093/rheumatology/39.6.655

48. Haagsma CJ, van Riel PL, de Jong AJ, van de Putte LB (1997) Combination of sulphasalazine and methotrexate versus the single components in early rheumatoid arthritis: a randomized, controlled, double-blind, 52 week clinical trial. Br J Rheumatol 36: 1082-1088

49. Hannonen P, Möttönen T, Hakola M, Oka M (1993) Sulfasalazine in early rheumatoid arthritis. A 48-week double-blind, prospective, placebo-controlled study. Arthritis Rheum 36:1501-1509

50. Sharp JT, Strand V, Leung H, Hurley F, Loew-Friedrich I (2000) Treatment with leflunomide slows radiographic progression of rheumatoid arthritis: results from three randomized controlled trials of leflunomide in patients with active rheumatoid arthritis. Leflunomide Rheumatoid Arthritis Investigators Group. Arthritis Rheum 43:495-505. https://doi.org/10.1002/1529-0131(200003) 43:3<495::AID-ANR4>3.0.CO;2-U

51. Smolen JS, Kalden JR, Scott DL, Rozman B, Kvien TK, Larsen A, Loew-Friedrich I, Oed C, Rosenburg R (1999) Efficacy and safety of leflunomide compared with placebo and sulphasalazine in active rheumatoid arthritis: a double-blind, randomised, multicentre trial. European Leflunomide Study Group. Lancet Lond Engl 353:259-266. https://doi.org/10.1016/s01406736(98)09403-3

52. Strand V, Cohen S, Schiff M et al (1999) Treatment of active rheumatoid arthritis with leflunomide compared with placebo and methotrexate. Leflunomide Rheumatoid Arthritis Investigators Group. Arch Intern Med 159:2542-2550

53. Clark P, Casas E, Tugwell P et al (1993) Hydroxychloroquine compared with placebo in rheumatoid arthritis. A randomized controlled trial. Ann Intern Med 119:1067-1071. https://oi.org/ 10.7326/0003-4819-119-11-199312010-00002

54. The HERA Study Group (1995) A randomized trial of hydroxychloroquine in early rheumatoid arthritis: the HERA study. Am J Med 98:156-168. https://doi.org/10.1016/s00029343(99)80399-4

55. Hung Y-M, Wang Y-H, Lin L, Wang PYP, Chiou JY, Wei JCC (2018) Hydroxychloroquine may be associated with reduced risk of coronary artery diseases in patients with rheumatoid arthritis: a nationwide population-based cohort study. Int J Clin Pract 72: e13095. https://doi.org/10.1111/ijcp.13095

56. Rempenault C, Combe B, Barnetche T, Gaujoux-Viala C, Lukas C, Morel J, Hua C (2018) Metabolic and cardiovascular benefits of hydroxychloroquine in patients with rheumatoid arthritis: a systematic review and meta-analysis. Ann Rheum Dis 77:98-103. https://doi.org/10.1136/annrheumdis-2017-211836

57. Sharma TS, Wasko MCM, Tang X, Vedamurthy D, Yan X, Cote J, Bili A (2016) Hydroxychloroquine use is associated with decreased incident cardiovascular events in rheumatoid arthritis patients. J Am Heart Assoc 5. https://doi.org/10.1161/JAHA.115. 002867

58. van der Heijde DM, van Riel PL, Nuver-Zwart IH, van de Putte LB (1990) Sulphasalazine versus hydroxychloroquine in rheumatoid arthritis: 3-year follow-up. Lancet Lond Engl 335:539. https:// doi.org/10.1016/0140-6736(90)90771-v

59. Bijlsma JWJ, Welsing PMJ, Woodworth TG, Middelink LM, Pethö-Schramm A, Bernasconi C, Borm MEA, Wortel CH, ter Borg EJ, Jahangier ZN, van der Laan WH, Bruyn GAW, Baudoin P, Wijngaarden S, Vos PAJM, Bos R, Starmans MJF, Griep EN, Griep-Wentink JRM, Allaart CF, Heurkens AHM, Teitsma XM, Tekstra J, Marijnissen ACA, Lafeber FPJ, Jacobs JWG (2016) Early rheumatoid arthritis treated with tocilizumab, methotrexate, or their combination (U-Act-Early): a multicentre, randomised, double-blind, double-dummy, strategy trial. Lancet Lond Engl 388:343-355. https://doi.org/10.1016/S01406736(16)30363-4

60. Burmester GR, Rigby WF, van Vollenhoven RF, Kay J, RubbertRoth A, Blanco R, Kadva A, Dimonaco S (2017) Tocilizumab combination therapy or monotherapy or methotrexate monotherapy in methotrexate-naive patients with early rheumatoid arthritis: 2-year clinical and radiographic results from the randomised, placebo-controlled FUNCTION trial. Ann Rheum Dis 76:12791284. https://doi.org/10.1136/annrheumdis-2016-210561

61. Dougados M, Kissel K, Sheeran T, Tak PP, Conaghan PG, Mola EM, Schett G, Amital H, Navarro-Sarabia F, Hou A, Bernasconi C, Huizinga TWJ (2013) Adding tocilizumab or switching to tocilizumab monotherapy in methotrexate inadequate responders: 24week symptomatic and structural results of a 2-year randomised controlled strategy trial in rheumatoid arthritis (ACT-RAY). Ann Rheum Dis 72:43-50. https://doi.org/10.1136/annrheumdis-2011201282

62. Fleischmann R, Schiff M, van der Heijde D, Ramos-Remus C, Spindler A, Stanislav M, Zerbini CAF, Gurbuz S, Dickson C, de Bono S, Schlichting D, Beattie S, Kuo WL, Rooney T, Macias W, Takeuchi T (2017) Baricitinib, methotrexate, or combination in patients with rheumatoid arthritis and no or limited prior diseasemodifying antirheumatic drug treatment. Arthritis Rheumatol Hoboken NJ 69:506-517. https://doi.org/10.1002/art.39953

63. Jones G, Sebba A, Gu J, Lowenstein MB, Calvo A, Gomez-Reino JJ, Siri DA, Tomsic M, Alecock E, Woodworth T, Genovese MC (2010) Comparison of tocilizumab monotherapy versus methotrexate monotherapy in patients with moderate to severe rheumatoid arthritis: the AMBITION study. Ann Rheum Dis 69:88-96. https://doi.org/10.1136/ard.2008.105197

64. Lee EB, Fleischmann R, Hall S, Wilkinson B, Bradley JD, Gruben D, Koncz T, Krishnaswami S, Wallenstein GV, Zang C, Zwillich SH, van Vollenhoven R, ORAL Start Investigators (2014) Tofacitinib versus methotrexate in rheumatoid arthritis. N Engl J Med 370:2377-2386. https://doi.org/10.1056/NEJMoa1310476

65. Hørslev-Petersen K, Hetland ML, Ørnbjerg LM, Junker P, Pødenphant J, Ellingsen T, Ahlquist P, Lindegaard H, Linauskas A, Schlemmer A, Dam MY, Hansen I, Lottenburger T, Ammitzbøll CG, Jørgensen A, Krintel SB, Raun J, Johansen JS, Østergaard M, Stengaard-Pedersen K, OPERA Study-Group (2016) Clinical and radiographic outcome of a treat-to-target 
strategy using methotrexate and intra-articular glucocorticoids with or without adalimumab induction: a 2-year investigator-initiated, double-blinded, randomised, controlled trial (OPERA). Ann Rheum Dis 75:1645-1653. https://doi.org/10.1136/ annrheumdis-2015-208166

66. Markusse IM, Akdemir G, Dirven L, Goekoop-Ruiterman YPM, van Groenendael JHLM, Han KH, Molenaar THE, le Cessie S, Lems WF, van der Lubbe PAHM, Kerstens PJSM, Peeters AJ, Ronday HK, de Sonnaville PBJ, Speyer I, Stijnen T, ten Wolde S, Huizinga TWJ, Allaart CF (2016) Long-term outcomes of patients with recent-onset rheumatoid arthritis after 10 years of tight controlled treatment: a randomized trial. Ann Intern Med 164: 523-531. https://doi.org/10.7326/M15-0919

67. Nam JL, Villeneuve E, Hensor EMA, Wakefield RJ, Conaghan PG, Green MJ, Gough A, Quinn M, Reece R, Cox SR, Buch MH, van der Heijde DM, Emery P (2014) A randomised controlled trial of etanercept and methotrexate to induce remission in early inflammatory arthritis: the EMPIRE trial. Ann Rheum Dis 73: 1027-1036. https://doi.org/10.1136/annrheumdis-2013-204882

68. Nam JL, Villeneuve E, Hensor EMA, Conaghan PG, Keen HI, Buch MH, Gough AK, Green MJ, Helliwell PS, Keenan AM, Morgan AW, Quinn M, Reece R, van der Heijde DM, Wakefield RJ, Emery P (2014) Remission induction comparing infliximab and high-dose intravenous steroid, followed by treat-to-target: a double-blind, randomised, controlled trial in new-onset, treatmentnaive, rheumatoid arthritis (the IDEA study). Ann Rheum Dis 73: 75-85. https://doi.org/10.1136/annrheumdis-2013-203440

69. Singh JA, Hossain A, Mudano AS, Tanjong Ghogomu E, SuarezAlmazor ME, Buchbinder R, Maxwell LJ, Tugwell P, Wells GA, Cochrane Musculoskeletal Group (2017) Biologics or tofacitinib for people with rheumatoid arthritis naive to methotrexate: a systematic review and network meta-analysis. Cochrane Database Syst Rev 5:CD012657. https://doi.org/10.1002/14651858. CD012657

70. Teitsma XM, Jacobs JWG, Welsing PMJ, Pethö-Schramm A, Borm MEA, van Laar JM, Lafeber FPJG, Bijlsma JWJ (2018) Radiographic joint damage in early rheumatoid arthritis patients: comparing tocilizumab- and methotrexate-based treat-to-target strategies. Rheumatol Oxf Engl 57:309-317. https://doi.org/10. 1093/rheumatology/kex386

71. Kavanaugh A, van Vollenhoven RF, Fleischmann R, Emery P, Sainsbury I, Florentinus S, Chen S, Guérette B, Kupper H, Smolen JS (2018) Testing treat-to-target outcomes with initial methotrexate monotherapy compared with initial tumour necrosis factor inhibitor (adalimumab) plus methotrexate in early rheumatoid arthritis. Ann Rheum Dis 77:289-292. https://doi.org/10. 1136/annrheumdis-2017-211871

72. Smolen JS, Emery P, Fleischmann R, van Vollenhoven RF, Pavelka K, Durez P, Guérette B, Kupper H, Redden L, Arora V, Kavanaugh A (2014) Adjustment of therapy in rheumatoid arthritis on the basis of achievement of stable low disease activity with adalimumab plus methotrexate or methotrexate alone: the randomised controlled OPTIMA trial. Lancet Lond Engl 383: 321-332. https://doi.org/10.1016/S0140-6736(13)61751-1

73. Choy EHS, Smith CM, Farewell V, Walker D, Hassell A, Chau L, Scott DL, for the CARDERA (Combination Anti-Rheumatic Drugs in Early Rheumatoid Arhritis) Trial Group (2008) Factorial randomised controlled trial of glucocorticoids and combination disease modifying drugs in early rheumatoid arthritis. Ann Rheum Dis 67:656-663. https://doi.org/10.1136/ard.2007. 076299

74. de Jong PH, Hazes JM, Han HK, Huisman M, van Zeben D, van der Lubbe PA, Gerards AH, van Schaeybroeck B, de Sonnaville PB, van Krugten MV, Luime JJ, Weel AE (2014) Randomised comparison of initial triple DMARD therapy with methotrexate monotherapy in combination with low-dose glucocorticoid bridging therapy; 1-year data of the tREACH trial. Ann Rheum Dis 73:1331-1339. https://doi.org/10.1136/annrheumdis-2013204788

75. den Uyl D, ter Wee M, Boers M, Kerstens P, Voskuyl A, Nurmohamed M, Raterman H, van Schaardenburg D, van Dillen N, Dijkmans B, Lems W (2014) A non-inferiority trial of an attenuated combination strategy ('COBRA-light') compared to the original COBRA strategy: clinical results after 26 weeks. Ann Rheum Dis 73:1071-1078. https://doi.org/10.1136/annrheumdis2012-202818

76. Konijn NPC, van Tuyl LHD, Boers M, den Uyl D, ter Wee MM, van der Wijden LKM, Bultink IEM, Kerstens PJSM, Voskuyl AE, van Schaardenburg D, Nurmohamed MT, Lems WF (2017) Similar efficacy and safety of initial COBRA-light and COBRA therapy in rheumatoid arthritis: 4-year results from the COBRAlight trial. Rheumatol Oxf Engl 56:1586-1596. https://doi.org/10. 1093/rheumatology/kex223

77. van der Veen MJ, Bijlsma JW (1993) The effect of methylprednisolone pulse therapy on methotrexate treatment of rheumatoid arthritis. Clin Rheumatol 12:500-505

78. Ammitzbøll-Danielsen M, Østergaard M, Fana V, Glinatsi D, Døhn UM, Ørnbjerg LM, Naredo E, Terslev L (2017) Intramuscular versus ultrasound-guided intratenosynovial glucocorticoid injection for tenosynovitis in patients with rheumatoid arthritis: a randomised, double-blind, controlled study. Ann Rheum Dis 76:666-672. https://doi.org/10.1136/annrheumdis2016-209840

79. del Rincón I, Battafarano DF, Restrepo JF, Erikson JM, Escalante A (2014) Glucocorticoid dose thresholds associated with all-cause and cardiovascular mortality in rheumatoid arthritis. Arthritis Rheumatol Hoboken NJ 66:264-272. https://doi.org/10.1002/art. 38210

80. Verschueren P, De Cock D, Corluy L et al (2017) Effectiveness of methotrexate with step-down glucocorticoid remission induction (COBRA Slim) versus other intensive treatment strategies for early rheumatoid arthritis in a treat-to-target approach: 1-year results of CareRA, a randomised pragmatic open-label superiority trial. Ann Rheum Dis 76:511-520. https://doi.org/10.1136/ annrheumdis-2016-209212

81. Gaujoux-Viala C, Gossec L (2014) When and for how long should glucocorticoids be used in rheumatoid arthritis? International guidelines and recommendations. Ann N Y Acad Sci 1318:32 40. https://doi.org/10.1111/nyas. 12452

82. Aletaha D, Alasti F, Smolen JS (2016) Optimisation of a treat-totarget approach in rheumatoid arthritis: strategies for the 3-month time point. Ann Rheum Dis 75:1479-1485. https://doi.org/10. 1136/annrheumdis-2015-208324

83. Bansback N, Phibbs CS, Sun H, O'Dell JR, Brophy M, Keystone EC, Leatherman S, Mikuls TR, Anis AH, for the CSP 551 RACAT Investigators (2017) Triple therapy versus biologic therapy for active rheumatoid arthritis: a cost-effectiveness analysis. Ann Intern Med 167:8-16. https://doi.org/10.7326/M16-0713

84. Eriksson JK, Karlsson JA, Bratt J, Petersson IF, van Vollenhoven RF, Ernestam S, Geborek P, Neovius M (2015) Cost-effectiveness of infliximab versus conventional combination treatment in methotrexate-refractory early rheumatoid arthritis: 2-year results of the register-enriched randomised controlled SWEFOT trial. Ann Rheum Dis 74:1094-1101. https://doi.org/10.1136/ annrheumdis-2013-205060

85. Hazlewood GS, Barnabe C, Tomlinson G, Marshall D, Devoe DJA, Bombardier C, Cochrane Musculoskeletal Group (2016) Methotrexate monotherapy and methotrexate combination therapy with traditional and biologic disease modifying anti-rheumatic drugs for rheumatoid arthritis: a network meta-analysis. Cochrane Database Syst Rev:CD010227. https://doi.org/10. 1002/14651858.CD010227.pub2 
86. Kremer JM, Genovese MC, Cannon GW, Caldwell JR, Cush JJ, Furst DE, Luggen ME, Keystone E, Weisman MH, Bensen WM, Kaine JL, Ruderman EM, Coleman P, Curtis DL, Kopp EJ, Kantor SM, Waltuck J, Lindsley HB, Markenson JA, Strand V, Crawford B, Fernando I, Simpson K, Bathon JM (2002) Concomitant leflunomide therapy in patients with active rheumatoid arthritis despite stable doses of methotrexate. A randomized, double-blind, placebo-controlled trial. Ann Intern Med 137:726-733. https:// doi.org/10.7326/0003-4819-137-9-200211050-00007

87. Moreland LW, O'Dell JR, Paulus HE et al (2012) A randomized comparative effectiveness study of oral triple therapy versus etanercept plus methotrexate in early aggressive rheumatoid arthritis: the treatment of Early Aggressive Rheumatoid Arthritis Trial. Arthritis Rheum 64:2824-2835. https://doi.org/10.1002/ art.34498

88. Möttönen T, Hannonen P, Leirisalo-Repo M, Nissilä M, Kautiainen H, Korpela M, Laasonen L, Julkunen H, Luukkainen R, Vuori K, Paimela L, Blåfield H, Hakala M, Ilva K, Yli-Kerttula U, Puolakka K, Järvinen P, Hakola M, Piirainen H, Ahonen J, Pälvimäki I, Forsberg S, Koota K, Friman C (1999) Comparison of combination therapy with single-drug therapy in early rheumatoid arthritis: a randomised trial. FIN-RACo trial group. Lancet Lond Engl 353:1568-1573. https://doi.org/10.1016/s01406736(98)08513-4

89. O'Dell JR, Mikuls TR, Taylor TH et al (2013) Therapies for active rheumatoid arthritis after methotrexate failure. N Engl J Med 369: 307-318. https://doi.org/10.1056/NEJMoa1303006

90. O'Dell JR, Haire CE, Erikson N et al (1996) Treatment of rheumatoid arthritis with methotrexate alone, sulfasalazine and hydroxychloroquine, or a combination of all three medications. N Engl J Med 334:1287-1291. https://doi.org/10.1056/ NEJM199605163342002

91. Peper SM, Lew R, Mikuls T, Brophy M, Rybin D, Wu H, O'Dell J (2017) Rheumatoid arthritis treatment after methotrexate: the durability of triple therapy versus etanercept. Arthritis Care Res 69: 1467-1472. https://doi.org/10.1002/acr.23255

92. van Vollenhoven RF, Geborek P, Forslind K, Albertsson K, Ernestam S, Petersson IF, Chatzidionysiou K, Bratt J (2012) Conventional combination treatment versus biological treatment in methotrexate-refractory early rheumatoid arthritis: 2 year follow-up of the randomised, non-blinded, parallel-group Swefot trial. Lancet Lond Engl 379:1712-1720. https://doi.org/10.1016/ S0140-6736(12)60027-0

93. Chatzidionysiou K, Emamikia S, Nam J, Ramiro S, Smolen J, van der Heijde D, Dougados M, Bijlsma J, Burmester G, Scholte M, van Vollenhoven R, Landewé R (2017) Efficacy of glucocorticoids, conventional and targeted synthetic disease-modifying antirheumatic drugs: a systematic literature review informing the 2016 update of the EULAR recommendations for the management of rheumatoid arthritis. Ann Rheum Dis 76:1102-1107. https://doi.org/10.1136/annrheumdis-2016-210711

94. Verschueren P, De Cock D, Corluy L et al (2015) Methotrexate in combination with other DMARDs is not superior to methotrexate alone for remission induction with moderate-to-high-dose glucocorticoid bridging in early rheumatoid arthritis after 16 weeks of treatment: the CareRA trial. Ann Rheum Dis 74:27-34. https:// doi.org/10.1136/annrheumdis-2014-205489

95. Goekoop-Ruiterman YPM, de Vries-Bouwstra JK, Allaart CF, van Zeben D, Kerstens PJ, Hazes JM, Zwinderman AH, Peeters AJ, de Jonge-Bok JM, Mallée C, de Beus WM, de Sonnaville PB, Ewals JA, Breedveld FC, Dijkmans BA (2007) Comparison of treatment strategies in early rheumatoid arthritis: a randomized trial. Ann Intern Med 146:406-415. https://doi.org/10.7326/0003-4819146-6-200703200-00005

96. Mazouyès A, Clay M, Bernard A-C, Gaudin P, Baillet A (2017) Efficacy of triple association methotrexate, sulfasalazine and hydroxychloroquine in early treatment of rheumatoid arthritis with insufficient response to methotrexate: meta-analysis of randomized controlled trials. Jt Bone Spine Rev Rhum 84:563-570. https://doi.org/10.1016/j.jbspin.2016.10.010

97. Frisell T, Baecklund E, Bengtsson K, di Giuseppe D, Forsbladd'Elia H, Askling J, ARTIS Study group (2018) Patient characteristics influence the choice of biological drug in RA, and will make non-TNFi biologics appear more harmful than TNFi biologics. Ann Rheum Dis 77:650-657. https://doi.org/10.1136/ annrheumdis-2017-212395

98. Curtis JR, Yang S, Patkar NM, Chen L, Singh JA, Cannon GW, Mikuls TR, Delzell E, Saag KG, Safford MM, DuVall S, Alexander K, Napalkov P, Winthrop KL, Burton MJ, Kamauu A, Baddley JW (2014) Risk of hospitalized bacterial infections associated with biologic treatment among US veterans with rheumatoid arthritis. Arthritis Care Res 66:990-997. https://doi.org/10. 1002/acr.22281

99. Richter A, Listing J, Schneider M, Klopsch T, Kapelle A, Kaufmann J, Zink A, Strangfeld A (2016) Impact of treatment with biologic DMARDs on the risk of sepsis or mortality after serious infection in patients with rheumatoid arthritis. Ann Rheum Dis 75:1667-1673. https://doi.org/10.1136/annrheumdis-2015207838

100. Schenfeld J, Iles J, Trivedi M, Accortt NA (2017) Dose relationship between oral glucocorticoids and tumor necrosis factor inhibitors and the risk of hospitalized infectious events among patients with rheumatoid arthritis. Rheumatol Int 37:1075-1082. https:// doi.org/10.1007/s00296-017-3679-4

101. Schoels M, Aletaha D, Smolen JS, Wong JB (2012) Comparative effectiveness and safety of biological treatment options after tumour necrosis factor $\alpha$ inhibitor failure in rheumatoid arthritis: systematic review and indirect pairwise meta-analysis. Ann Rheum Dis 71:1303-1308. https://doi.org/10.1136/annrheumdis2011-200490

102. Singh JA, Hossain A, Tanjong Ghogomu E, Mudano AS, Maxwell LJ, Buchbinder R, Lopez-Olivo MA, Suarez-Almazor ME, Tugwell P, Wells GA, Cochrane Musculoskeletal Group (2017) Biologics or tofacitinib for people with rheumatoid arthritis unsuccessfully treated with biologics: a systematic review and network meta-analysis. Cochrane Database Syst Rev 3: CD012591. https://doi.org/10.1002/14651858.CD012591

103. Manders SHM, Kievit W, Adang E, Brus HL, Moens HJB, Hartkamp A, Hendriks L, Brouwer E, Visser H, Vonkeman HE, Hendrikx J, Jansen TL, Westhovens R, van de Laar MAFJ, van Riel PLCM (2015) Cost-effectiveness of abatacept, rituximab, and TNFi treatment after previous failure with TNFi treatment in rheumatoid arthritis: a pragmatic multi-centre randomised trial. Arthritis Res Ther 17:134. https://doi.org/10.1186/s13075-0150630-5

104. Torrente-Segarra V, Acosta Pereira A, Morla R, Ruiz JM, Clavaguera T, Figuls R, Corominas H, Geli C, Roselló R, de Agustín JJ, Alegre C, Pérez C, García A, Rodríguez de la Serna A (2016) VARIAR study: assessment of short-term efficacy and safety of rituximab compared to an tumor necrosis factor alpha antagonists as second-line drug therapy in patients with rheumatoid arthritis refractory to a first tumor necrosis factor alpha antagonist. Reumatol Clin 12:319-322. https://doi.org/10.1016/j. reuma.2015.11.019

105. Gottenberg J-E, Brocq O, Perdriger A, Lassoued S, Berthelot JM, Wendling D, Euller-Ziegler L, Soubrier M, Richez C, Fautrel B, Constantin AL, Mariette X, Morel J, Gilson M, Cormier G, Salmon JH, Rist S, Lioté F, Marotte H, Bonnet C, Marcelli C, Sellam J, Meyer O, Solau-Gervais E, Guis S, Ziza JM, Zarnitsky C, Chary-Valckenaere I, Vittecoq O, Saraux A, Pers YM, Gayraud M, Bolla G, Claudepierre P, Ardizzone M, Dernis E, Breban MA, Fain O, Balblanc JC, Aberkane O, Vazel M, Back C, Candon S, 
Chatenoud L, Perrodeau E, Sibilia J, Ravaud P (2016) Non-TNFtargeted biologic vs a second anti-TNF drug to treat rheumatoid arthritis in patients with insufficient response to a first anti-TNF drug: a randomized clinical trial. JAMA 316:1172-1180. https:// doi.org/10.1001/jama.2016.13512

106. Schiff MH, von Kempis J, Goldblum R, Tesser JR, Mueller RB (2014) Rheumatoid arthritis secondary non-responders to TNF can attain an efficacious and safe response by switching to certolizumab pegol: a phase IV, randomised, multicentre, double-blind, 12-week study, followed by a 12-week open-label phase. Ann Rheum Dis 73:2174-2177. https://doi.org/10.1136/ annrheumdis-2014-205325

107. Smolen JS, Burmester G-R, Combe B, Curtis JR, Hall S, Haraoui B, van Vollenhoven R, Cioffi C, Ecoffet C, Gervitz L, Ionescu L, Peterson L, Fleischmann R (2016) Head-to-head comparison of certolizumab pegol versus adalimumab in rheumatoid arthritis: 2year efficacy and safety results from the randomised EXXELERATE study. Lancet Lond Engl 388:2763-2774. https://doi.org/10.1016/S0140-6736(16)31651-8

108. Genovese MC, Kremer J, Zamani O, Ludivico C, Krogulec M, Xie L, Beattie SD, Koch AE, Cardillo TE, Rooney TP, Macias WL, de Bono S, Schlichting DE, Smolen JS (2016) Baricitinib in patients with refractory rheumatoid arthritis. N Engl J Med 374: 1243-1252. https://doi.org/10.1056/NEJMoa1507247

109. Emery P, van Hoogstraten H, Jayawardena S et al (2017) Efficacy of sarilumab in patients with rheumatoid arthritis who previously received sarilumab or tocilizumab. Arthritis Rheumatol Hoboken NJ 69:Abstract 2468

110. Verschueren P, Emery P, van Hoogstraten H et al (2018) THU0215 efficacy of sarilumab in patients with rheumatoid arthritis with and without previous response to tocilizumab. Ann Rheum Dis 77: 327-328 https://doi.org/10.1136/annrheumdis-2018-eular.1376

111. Emery P, Rondon J, Parrino J, Lin Y, Pena-Rossi C, van Hoogstraten H, Graham NMH, Liu N, Paccaly A, Wu R, Spindler A (2018) Safety and tolerability of subcutaneous sarilumab and intravenous tocilizumab in patients with rheumatoid arthritis. Rheumatol Oxf Engl 58:849-858. https://doi.org/10. 1093/rheumatology/key361

112. Abe A, Ishikawa H, Nakazono K, Murasawa A, Wakaki K (2016) A comparison of the ultrasonography images of the joints of patients with rheumatoid arthritis and the corresponding synovial histological findings. Mod Rheumatol 26:534-539. https://oi. org/10.3109/14397595.2015.1106680

113. Lai K-L, Chen D-Y, Wen M-C, Chen YM, Hung WT, Chen YH, Chen HH (2018) What does power Doppler signal indicate in rheumatoid synovitis? A point of view from synovial histopathology. J Chin Med Assoc JCMA 81:383-386. https://doi.org/10. 1016/j.jcma.2016.07.008

114. Xiao H, Liu M, Tan L, Liao X, Li Y, Gao J, Li F, Xie X, Peng Q, Mao N, Tian J, du J, Chen J (2014) Value of ultrasonography for diagnosis of synovitis associated with rheumatoid arthritis. Int $\mathrm{J}$ Rheum Dis 17:767-775. https://doi.org/10.1111/1756-185X. 12390

115. Hmamouchi I, Bahiri R, Srifi N, Aktaou S, Abouqal R, HajjajHassouni N (2011) A comparison of ultrasound and clinical examination in the detection of flexor tenosynovitis in early arthritis. BMC Musculoskelet Disord 12:91. https://doi.org/10.1186/14712474-12-91

116. Szkudlarek M, Narvestad E, Klarlund M, Court-Payen M, Thomsen HS, Østergaard M (2004) Ultrasonography of the metatarsophalangeal joints in rheumatoid arthritis: comparison with magnetic resonance imaging, conventional radiography, and clinical examination. Arthritis Rheum 50:2103-2112. https://doi.org/10.1002/art.20333

117. Szkudlarek M, Klarlund M, Narvestad E, Court-Payen M, Strandberg C, Jensen KE, Thomsen HS, Østergaard M (2006)
Ultrasonography of the metacarpophalangeal and proximal interphalangeal joints in rheumatoid arthritis: a comparison with magnetic resonance imaging, conventional radiography and clinical examination. Arthritis Res Ther 8:R52. https://doi.org/10.1186/ ar1904

118. Zhang Y-H, Li K, Xiao J, Zhang HD, Zhang XY (2018) Comparison of ultrasound, radiography, and clinical investigations in the diagnosis of early rheumatoid synovitis in patients with nonspecific musculoskeletal symptoms: a multicenter cross-sectional study. Med Sci Monit Int Med J Exp Clin Res 24:4372-4378. https://doi.org/10.12659/MSM.908755

119. Colebatch AN, Edwards CJ, Østergaard M, van der Heijde D, Balint PV, D'Agostino MA, Forslind K, Grassi W, Haavardsholm EA, Haugeberg G, Jurik AG, Landewé RBM, Naredo E, O'Connor PJ, Ostendorf B, Potočki K, Schmidt WA, Smolen JS, Sokolovic S, Watt I, Conaghan PG (2013) EULAR recommendations for the use of imaging of the joints in the clinical management of rheumatoid arthritis. Ann Rheum Dis 72:804814. https://doi.org/10.1136/annrheumdis-2012-203158

120. Wakefield RJ, Green MJ, Marzo-Ortega H et al (2004) Should oligoarthritis be reclassified? Ultrasound reveals a high prevalence of subclinical disease. Ann Rheum Dis 63:382-385. https://doi. org/10.1136/ard.2003.007062

121. Dale J, Stirling A, Zhang R, Purves D, Foley J, Sambrook M, Conaghan PG, van der Heijde D, McConnachie A, McInnes IB, Porter D (2016) Targeting ultrasound remission in early rheumatoid arthritis: the results of the TaSER study, a randomised clinical trial. Ann Rheum Dis 75:1043-1050. https://doi.org/10.1136/ annrheumdis-2015-208941

122. Haavardsholm EA, Aga A-B, Olsen IC, Lillegraven S, Hammer HB, Uhlig T, Fremstad H, Madland TM, Lexberg ÅS, Haukeland H, Rødevand E, Høili C, Stray H, Noraas A, Hansen IJW, Bakland G, Nordberg LB, van der Heijde D, Kvien TK (2016) Ultrasound in management of rheumatoid arthritis: ARCTIC randomised controlled strategy trial. BMJ 354:i4205. https://doi.org/10.1136/bmj. i4205

123. Simpson E, Hock E, Stevenson M, Wong R, Dracup N, Wailoo A, Conaghan P, Estrach C, Edwards C, Wakefield R (2018) What is the added value of ultrasound joint examination for monitoring synovitis in rheumatoid arthritis and can it be used to guide treatment decisions? A systematic review and cost-effectiveness analysis. Health Technol Assess Winch Engl 22:1-258. https://doi.org/ 10.3310/hta22200

124. Choe J-Y, Prodanovic N, Niebrzydowski J, Staykov I, Dokoupilova E, Baranauskaite A, Yatsyshyn R, Mekic M, Porawska W, Ciferska H, Jedrychowicz-Rosiak K, Zielinska A, Choi J, Rho YH, Smolen JS (2017) A randomised, double-blind, phase III study comparing SB2, an infliximab biosimilar, to the infliximab reference product Remicade in patients with moderate to severe rheumatoid arthritis despite methotrexate therapy. Ann Rheum Dis 76:58-64. https://doi.org/10.1136/annrheumdis2015-207764

125. Emery P, Vencovský J, Sylwestrzak A, Leszczyński P, Porawska W, Baranauskaite A, Tseluyko V, Zhdan VM, Stasiuk B, Milasiene R, Barrera Rodriguez AA, Cheong SY, Ghil J (2017) A phase III randomised, double-blind, parallel-group study comparing SB4 with etanercept reference product in patients with active rheumatoid arthritis despite methotrexate therapy. Ann Rheum Dis 76:51-57. https://doi.org/10.1136/annrheumdis2015-207588

126. Takeuchi T, Yamanaka H, Tanaka Y, Sakurai T, Saito K, Ohtsubo H, Lee SJ, Nambu Y (2015) Evaluation of the pharmacokinetic equivalence and 54-week efficacy and safety of CT-P13 and innovator infliximab in Japanese patients with rheumatoid arthritis. Mod Rheumatol 25:817-824. https://doi.org/10.3109/14397595. 2015.1022297 
127. Yoo DH, Hrycaj P, Miranda P, Ramiterre E, Piotrowski M, Shevchuk S, Kovalenko V, Prodanovic N, Abello-Banfi M, Gutierrez-Ureña S, Morales-Olazabal L, Tee M, Jimenez R, Zamani O, Lee SJ, Kim HU, Park W, Müller-Ladner U (2013) A randomised, double-blind, parallel-group study to demonstrate equivalence in efficacy and safety of CT-P13 compared with innovator infliximab when coadministered with methotrexate in patients with active rheumatoid arthritis: the PLANETRA study. Ann Rheum Dis 72:1613-1620. https://doi.org/10.1136/ annrheumdis-2012-203090

128. Yoo DH, Racewicz A, Brzezicki J, Yatsyshyn R, Arteaga ET, Baranauskaite A, Abud-Mendoza C, Navarra S, Kadinov V, Sariego IG, Hong SS, Lee SY, Park W (2016) A phase III randomized study to evaluate the efficacy and safety of CT-P13 compared with reference infliximab in patients with active rheumatoid arthritis: 54-week results from the PLANETRA study. Arthritis Res Ther 18:82. https://doi.org/10.1186/s13075-016-0981-6

129. Emery P, Vencovský J, Sylwestrzak A, Leszczyński P, Porawska W, Stasiuk B, Hilt J, Mosterova Z, Cheong SY, Ghil J (2017) Long-term efficacy and safety in patients with rheumatoid arthritis continuing on SB4 or switching from reference etanercept to SB4. Ann Rheum Dis 76:1986-1991. https://doi.org/10.1136/ annrheumdis-2017-211591

130. Park W, Suh C-H, Shim SC, Molina FFC, Jeka S, MedinaRodriguez FG, Hrycaj P, Wiland P, Lee EY, Shesternya P, Kovalenko V, Myasoutova L, Stanislav M, Radominski S, Lim MJ, Choe JY, Lee SJ, Lee SY, Kim SH, Yoo DH (2017) Efficacy and safety of switching from innovator rituximab to biosimilar CT-P10 compared with continued treatment with CT-P10: results of a 56-week open-label study in patients with rheumatoid arthritis. BioDrugs Clin Immunother Biopharm Gene Ther 31:369377. https://doi.org/10.1007/s40259-017-0233-6

131. Smolen JS, Choe J-Y, Prodanovic N, Niebrzydowski J, Staykov I, Dokoupilova E, Baranauskaite A, Yatsyshyn R, Mekic M, Porawska W, Ciferska H, Jedrychowicz-Rosiak K, Zielinska A, Lee Y, Rho YH (2018) Safety, immunogenicity and efficacy after switching from reference infliximab to biosimilar SB2 compared with continuing reference infliximab and SB2 in patients with rheumatoid arthritis: results of a randomised, double-blind, phase III transition study. Ann Rheum Dis 77:234-240. https://doi.org/ 10.1136/annrheumdis-2017-211741

132. Tanaka Y, Yamanaka H, Takeuchi T, Inoue M, Saito K, Saeki Y, Lee SJ, Nambu Y (2017) Safety and efficacy of CT-P13 in Japanese patients with rheumatoid arthritis in an extension phase or after switching from infliximab. Mod Rheumatol 27:237-245. https://doi.org/10.1080/14397595.2016.1206244

133. Weinblatt ME, Baranauskaite A, Dokoupilova E, Zielinska A, Jaworski J, Racewicz A, Pileckyte M, Jedrychowicz-Rosiak K, Baek I, Ghil J (2018) Switching from reference adalimumab to SB5 (adalimumab biosimilar) in patients with rheumatoid arthritis: fifty-two-week phase III randomized study results. Arthritis Rheumatol Hoboken NJ 70:832-840. https://doi.org/10.1002/art. 40444

134. Yoo DH, Prodanovic N, Jaworski J, Miranda P, Ramiterre E, Lanzon A, Baranauskaite A, Wiland P, Abud-Mendoza C, Oparanov B, Smiyan S, Kim HU, Lee SJ, Kim SY, Park W (2017) Efficacy and safety of CT-P13 (biosimilar infliximab) in patients with rheumatoid arthritis: comparison between switching from reference infliximab to CT-P13 and continuing CT-P13 in the PLANETRA extension study. Ann Rheum Dis 76:355-363. https://doi.org/10.1136/annrheumdis-2015-208786

135. Jørgensen KK, Olsen IC, Goll GL, Lorentzen M, Bolstad N, Haavardsholm EA, Lundin KEA, Mørk C, Jahnsen J, Kvien TK, Berset IP, Fevang BTS, Florholmen J, Kalstad S, Mørk NJ, Ryggen K, Tveit KS, Sæther SK, Gulbrandsen B, Hagfors J, Waksvik K, Warren D, Henanger KJ, Asak Ø, Baigh S,
Blomgren IM, Bruun TJ, Dvergsnes K, Frigstad SO, Gjesdal CG, Grandaunet BHJ, Hansen IM, Hatten ISH, Huppertz-Hauss G, Henriksen M, Hoie SS, Krogh J, Kruse JR, Ljoså MKA, Midtgard IP, Mielnik P, Moum B, Noraberg G, Poyan A, Prestegård U, Rashid HU, Rydning JH, Sagatun L, Seeberg KA, Skjetne K, Strand EK, Stray H, Stray N, Torp R, Vold C, Ystrøm CM, Zettel CC (2017) Switching from originator infliximab to biosimilar CT-P13 compared with maintained treatment with originator infliximab (NOR-SWITCH): a 52-week, randomised, double-blind, non-inferiority trial. Lancet Lond Engl 389:2304-2316. https://doi.org/10.1016/S0140-6736(17)30068-5

136. Glintborg B, Sørensen IJ, Loft AG, Lindegaard H, Linauskas A, Hendricks O, Hansen IMJ, Jensen DV, Manilo N, Espesen J, Klarlund M, Grydehøj J, Dieperink SS, Kristensen S, Olsen JS, Nordin H, Chrysidis S, Dalsgaard Pedersen D, Sørensen MV, Andersen LS, Grøn KL, Krogh NS, Pedersen L, Hetland ML (2017) A nationwide non-medical switch from originator infliximab to biosimilar CT-P13 in 802 patients with inflammatory arthritis: 1-year clinical outcomes from the DANBIO registry. Ann Rheum Dis 76:1426-1431. https://doi.org/10.1136/annrheumdis2016-210742

137. Kay J, Schoels MM, Dörner T, Emery P, Kvien TK, Smolen JS, Breedveld FC, Task Force on the Use of Biosimilars to Treat Rheumatological Diseases (2018) Consensus-based recommendations for the use of biosimilars to treat rheumatological diseases. Ann Rheum Dis 77:165-174. https://doi.org/10.1136/ annrheumdis-2017-211937

138. Emery P, Hammoudeh M, FitzGerald O, Combe B, Martin-Mola E, Buch MH, Krogulec M, Williams T, Gaylord S, Pedersen R, Bukowski J, Vlahos B (2014) Sustained remission with etanercept tapering in early rheumatoid arthritis. N Engl J Med 371:17811792. https://doi.org/10.1056/NEJMoa1316133

139. Westhovens R, Robles M, Ximenes AC, Wollenhaupt J, Durez P, Gomez-Reino J, Grassi W, Haraoui B, Shergy W, Park SH, Genant H, Peterfy C, Becker JC, Murthy B (2015) Maintenance of remission following 2 years of standard treatment then dose reduction with abatacept in patients with early rheumatoid arthritis and poor prognosis. Ann Rheum Dis 74:564-568. https://doi.org/10.1136/ annrheumdis-2014-206149

140. Detert J, Bastian H, Listing J, Weiß A, Wassenberg S, Liebhaber A, Rockwitz K, Alten R, Krüger K, Rau R, Simon C, Gremmelsbacher E, Braun T, Marsmann B, Höhne-Zimmer V, Egerer K, Buttgereit F, Burmester GR (2013) Induction therapy with adalimumab plus methotrexate for 24 weeks followed by methotrexate monotherapy up to week 48 versus methotrexate therapy alone for DMARD-naive patients with early rheumatoid arthritis: HIT HARD, an investigator-initiated study. Ann Rheum Dis 72:844-850. https://doi.org/10.1136/annrheumdis-2012201612

141. Emery P, Burmester GR, Bykerk VP, Combe BG, Furst DE, Barré E, Karyekar CS, Wong DA, Huizinga TWJ (2015) Evaluating drug-free remission with abatacept in early rheumatoid arthritis: results from the phase $3 \mathrm{~b}$, multicentre, randomised, activecontrolled AVERT study of 24 months, with a 12-month, double-blind treatment period. Ann Rheum Dis 74:19-26. https://doi.org/10.1136/annrheumdis-2014-206106

142. Klarenbeek NB, van der Kooij SM, Güler-Yüksel M et al (2011) Discontinuing treatment in patients with rheumatoid arthritis in sustained clinical remission: exploratory analyses from the BeSt study. Ann Rheum Dis 70:315-319. https://doi.org/10.1136/ard. 2010.136556

143. Quinn MA, Conaghan PG, O'Connor PJ et al (2005) Very early treatment with infliximab in addition to methotrexate in early, poor-prognosis rheumatoid arthritis reduces magnetic resonance imaging evidence of synovitis and damage, with sustained benefit after infliximab withdrawal: results from a twelve-month 
randomized, double-blind, placebo-controlled trial. Arthritis Rheum 52:27-35. https://doi.org/10.1002/art.20712

144. Fautrel B, Pham T, Alfaiate T, Gandjbakhch F, Foltz V, Morel J, Dernis E, Gaudin P, Brocq O, Solau-Gervais E, Berthelot JM, Balblanc JC, Mariette X, Tubach F (2016) Step-down strategy of spacing TNF-blocker injections for established rheumatoid arthritis in remission: results of the multicentre non-inferiority randomised open-label controlled trial (STRASS: Spacing of TNF-blocker injections in Rheumatoid ArthritiS Study). Ann Rheum Dis 75:59-67. https://doi.org/10.1136/annrheumdis2014-206696

145. Haschka J, Englbrecht M, Hueber AJ, Manger B, Kleyer A, Reiser M, Finzel S, Tony HP, Kleinert S, Feuchtenberger M, Fleck M, Manger K, Ochs W, Schmitt-Haendle M, Wendler J, Schuch F, Ronneberger M, Lorenz HM, Nuesslein H, Alten R, Demary W, Henes J, Schett G, Rech J (2016) Relapse rates in patients with rheumatoid arthritis in stable remission tapering or stopping antirheumatic therapy: interim results from the prospective randomised controlled RETRO study. Ann Rheum Dis 75:4551. https://doi.org/10.1136/annrheumdis-2014-206439

146. Smolen JS, Nash P, Durez P, Hall S, Ilivanova E, IrazoquePalazuelos F, Miranda P, Park MC, Pavelka K, Pedersen R, Szumski A, Hammond C, Koenig AS, Vlahos B (2013) Maintenance, reduction, or withdrawal of etanercept after treatment with etanercept and methotrexate in patients with moderate rheumatoid arthritis (PRESERVE): a randomised controlled trial. Lancet Lond Engl 381:918-929. https://doi.org/10.1016/S01406736(12)61811-X

147. van Herwaarden N, van der Maas A, Minten MJM, van den Hoogen FHJ, Kievit W, van Vollenhoven RF, Bijlsma JWJ, van den Bemt BJF, den Broeder AA (2015) Disease activity guided dose reduction and withdrawal of adalimumab or etanercept compared with usual care in rheumatoid arthritis: open label, randomised controlled, non-inferiority trial. BMJ 350:h1389. https://doi.org/10.1136/bmj.h1389

148. van Vollenhoven RF, Østergaard M, Leirisalo-Repo M, Uhlig T, Jansson M, Larsson E, Brock F, Franck-Larsson K (2016) Full dose, reduced dose or discontinuation of etanercept in rheumatoid arthritis. Ann Rheum Dis 75:52-58. https://doi.org/10.1136/ annrheumdis-2014-205726

149. Aguilar-Lozano L, Castillo-Ortiz JD, Vargas-Serafin C, MoralesTorres J, Sanchez-Ortiz A, Sandoval-Castro C, Padilla-Ibarra J, Hernandez-Cuevas C, Ramos-Remus C (2013) Sustained clinical remission and rate of relapse after tocilizumab withdrawal in patients with rheumatoid arthritis. J Rheumatol 40:1069-1073. https://doi.org/10.3899/jrheum.121427

150. Brocq O, Millasseau E, Albert C, Grisot C, Flory P, Roux CH, Euller-Ziegler L (2009) Effect of discontinuing TNFalpha antagonist therapy in patients with remission of rheumatoid arthritis. Jt Bone Spine Rev Rhum 76:350-355. https://doi.org/10.1016/j. jbspin.2008.11.009

151. Huizinga TWJ, Conaghan PG, Martin-Mola E, Schett G, Amital H, Xavier RM, Troum O, Aassi M, Bernasconi C, Dougados M (2015) Clinical and radiographic outcomes at 2 years and the effect of tocilizumab discontinuation following sustained remission in the second and third year of the ACT-RAY study. Ann Rheum Dis 74:35-43. https://doi.org/10.1136/annrheumdis2014-205752

152. Nishimoto N, Amano K, Hirabayashi Y, Horiuchi T, Ishii T, Iwahashi M, Iwamoto M, Kohsaka H, Kondo M, Matsubara T, Mimura T, Miyahara H, Ohta S, Saeki Y, Saito K, Sano H, Takasugi K, Takeuchi T, Tohma S, Tsuru T, Ueki Y, Yamana J, Hashimoto J, Matsutani T, Murakami M, Takagi N (2014) Drug free REmission/low disease activity after cessation of tocilizumab (Actemra) Monotherapy (DREAM) study. Mod Rheumatol 24: 17-25. https://doi.org/10.3109/14397595.2013.854079
153. Saleem B, Keen H, Goeb V, Parmar R, Nizam S, Hensor EMA, Churchman SM, Quinn M, Wakefield R, Conaghan PG, Ponchel F, Emery P (2010) Patients with RA in remission on TNF blockers: when and in whom can TNF blocker therapy be stopped? Ann Rheum Dis 69:1636-1642. https://doi.org/10. 1136/ard.2009.117341

154. Smolen JS, Emery P, Ferraccioli GF, Samborski W, Berenbaum F, Davies OR, Koetse W, Purcaru O, Bennett B, Burkhardt H (2015) Certolizumab pegol in rheumatoid arthritis patients with low to moderate activity: the CERTAIN double-blind, randomised, placebo-controlled trial. Ann Rheum Dis 74:843-850. https:// doi.org/10.1136/annrheumdis-2013-204632

155. Tanaka Y, Hirata S, Kubo S, Fukuyo S, Hanami K, Sawamukai N, Nakano K, Nakayamada S, Yamaoka K, Sawamura F, Saito K (2015) Discontinuation of adalimumab after achieving remission in patients with established rheumatoid arthritis: 1-year outcome of the HONOR study. Ann Rheum Dis 74:389-395. https://doi. org/10.1136/annrheumdis-2013-204016

156. Tanaka Y, Takeuchi T, Mimori T, Saito K, Nawata M, Kameda H, Nojima T, Miyasaka N, Koike T, for the RRR study investigators (2010) Discontinuation of infliximab after attaining low disease activity in patients with rheumatoid arthritis: RRR (remission induction by Remicade in RA) study. Ann Rheum Dis 69:12861291. https://doi.org/10.1136/ard.2009.121491

157. van der Maas A, Kievit W, van den Bemt BJF, van den Hoogen FHJ, van Riel PL, den Broeder AA (2012) Down-titration and discontinuation of infliximab in rheumatoid arthritis patients with stable low disease activity and stable treatment: an observational cohort study. Ann Rheum Dis 71:1849-1854. https://doi.org/10. 1136/annrheumdis-2011-200945

158. van Herwaarden N, Herfkens-Hol S, van der Maas A et al (2014) Dose reduction of tocilizumab in rheumatoid arthritis patients with low disease activity. Clin Exp Rheumatol 32:390-394

159. Schett G, Emery P, Tanaka Y, Burmester G, Pisetsky DS, Naredo E, Fautrel B, van Vollenhoven R (2016) Tapering biologic and conventional DMARD therapy in rheumatoid arthritis: current evidence and future directions. Ann Rheum Dis 75:1428-1437. https://doi.org/10.1136/annrheumdis-2016-209201

160. Alivernini S, Peluso G, Fedele AL, Tolusso B, Gremese E, Ferraccioli G (2016) Tapering and discontinuation of TNF- $\alpha$ blockers without disease relapse using ultrasonography as a tool to identify patients with rheumatoid arthritis in clinical and histological remission. Arthritis Res Ther 18:39. https://doi.org/10. 1186/s13075-016-0927-z

161. Iwamoto T, Ikeda K, Hosokawa J, Yamagata M, Tanaka S, Norimoto A, Sanayama Y, Nakagomi D, Takahashi K, Hirose K, Sugiyama T, Sueishi M, Nakajima H (2014) Prediction of relapse after discontinuation of biologic agents by ultrasonographic assessment in patients with rheumatoid arthritis in clinical remission: high predictive values of total gray-scale and power Doppler scores that represent residual synovial inflammation before discontinuation. Arthritis Care Res 66:1576-1581. https:// doi.org/10.1002/acr.22303

162. Naredo E, Valor L, De la Torre I et al (2015) Predictive value of Doppler ultrasound-detected synovitis in relation to failed tapering of biologic therapy in patients with rheumatoid arthritis. Rheumatol Oxf Engl 54:1408-1414. https://doi.org/10.1093/ rheumatology/kev006

163. Kuijper TM, Luime JJ, de Jong PHP, Gerards AH, van Zeben D, Tchetverikov I, de Sonnaville PBJ, van Krugten MV, Grillet BA, Hazes JMW, Weel AEAM (2016) Tapering conventional synthetic DMARDs in patients with early arthritis in sustained remission: 2year follow-up of the tREACH trial. Ann Rheum Dis 75:2119 2123. https://doi.org/10.1136/annrheumdis-2016-209272

164. Kuijper TM, Lamers-Karnebeek FBG, Jacobs JWG, Hazes JMW, Luime JJ (2015) Flare rate in patients with rheumatoid arthritis in 
low disease activity or remission when tapering or stopping synthetic or biologic DMARD: a systematic review. J Rheumatol 42: 2012-2022. https://doi.org/10.3899/jrheum.141520

165. Ahern MJ, Hall ND, Case K, Maddison PJ (1984) D-penicillamine withdrawal in rheumatoid arthritis. Ann Rheum Dis 43:213-217. https://doi.org/10.1136/ard.43.2.213

166. ten Wolde S, Breedveld FC, Hermans J et al (1996) Randomised placebo-controlled study of stopping second-line drugs in rheumatoid arthritis. Lancet Lond Engl 347:347-352. https://doi.org/10. 1016/s0140-6736(96)90535-8

167. Isaacs JD, Cohen SB, Emery P, Tak PP, Wang J, Lei G, Williams S, Lal P, Read SJ (2013) Effect of baseline rheumatoid factor and anticitrullinated peptide antibody serotype on rituximab clinical response: a meta-analysis. Ann Rheum Dis 72:329-336. https:// doi.org/10.1136/annrheumdis-2011-201117

168. Sokolove J, Schiff M, Fleischmann R, Weinblatt ME, Connolly SE, Johnsen A, Zhu J, Maldonado MA, Patel S, Robinson WH (2016) Impact of baseline anti-cyclic citrullinated peptide-2 antibody concentration on efficacy outcomes following treatment with subcutaneous abatacept or adalimumab: 2-year results from the AMPLE trial. Ann Rheum Dis 75:709-714. https://doi.org/10. 1136/annrheumdis-2015-207942

169. Götestam Skorpen C, Hoeltzenbein M, Tincani A, Fischer-Betz R, Elefant E, Chambers C, da Silva J, Nelson-Piercy C, Cetin I, Costedoat-Chalumeau N, Dolhain R, Förger F, Khamashta M, Ruiz-Irastorza G, Zink A, Vencovsky J, Cutolo M, Caeyers N, Zumbühl C, Østensen M (2016) The EULAR points to consider for use of antirheumatic drugs before pregnancy, and during pregnancy and lactation. Ann Rheum Dis 75:795-810. https://doi.org/ 10.1136/annrheumdis-2015-208840

170. Burmester GR, Landewé R, Genovese MC, Friedman AW, Pfeifer ND, Varothai NA, Lacerda AP (2017) Adalimumab long-term safety: infections, vaccination response and pregnancy outcomes in patients with rheumatoid arthritis. Ann Rheum Dis 76:414-417. https://doi.org/10.1136/annrheumdis-2016-209322

171. Julsgaard M, Christensen LA, Gibson PR, Gearry RB, Fallingborg J, Hvas CL, Bibby BM, Uldbjerg N, Connell WR, Rosella O, Grosen A, Brown SJ, Kjeldsen J, Wildt S, Svenningsen L, Sparrow MP, Walsh A, Connor SJ, Radford-Smith G, Lawrance IC, Andrews JM, Ellard K, Bell SJ (2016) Concentrations of adalimumab and infliximab in mothers and newborns, and effects on infection. Gastroenterology 151:110-119. https://doi.org/10. 1053/j.gastro.2016.04.002

172. Chen Y-M, Yang S-S, Chen D-Y (2019) Risk-stratified management strategies for HBV reactivation in RA patients receiving biological and targeted therapy: a narrative review. J Microbiol Immunol Infect Wei Mian Yu Gan Ran Za Zhi 52:1-8. https:// doi.org/10.1016/j.jmii.2017.10.002

173. Dragonas C, Ehrenstein B, Fleck M (2012) Tocilizumab treatment in a patient suffering from rheumatoid arthritis and concomitant chronic hepatitis C infection. Rheumatol Oxf Engl 51:1520-1521. https://doi.org/10.1093/rheumatology/kes051

174. Iannone F, La Montagna G, Bagnato G et al (2014) Safety of etanercept and methotrexate in patients with rheumatoid arthritis and hepatitis $\mathrm{C}$ virus infection: a multicenter randomized clinical trial. J Rheumatol 41:286-292. https://doi.org/10.3899/jrheum. 130658

175. Joseph AM (2012) Treatment of rheumatoid arthritis in patients with concomitant chronic hepatitis $\mathrm{C}$ infection. Ther Adv Musculoskelet Dis 4:35-40. https://doi.org/10.1177/ $1759720 X 11424459$

176. Mahajan TD, Hooker R, Maher L, Brown G, Reimold A (2010) Abatacept therapy for rheumatoid arthritis in the setting of hepatitis C infection. J Clin Rheumatol Pract Rep Rheum Musculoskelet Dis 16:332-334. https://doi.org/10.1097/RHU. 0b013e3181f4cd92

177. Nagashima T, Maruyama A, Kamata Y, Minota S (2012) Unchanged serum viral load and liver function during tocilizumab treatment in a patient with rheumatoid arthritis and hepatitis $\mathrm{C}$ virus infection. Rheumatol Int 32:2231-2232. https://doi.org/10. 1007/s00296-011-2060-2

178. Jeka S, Dura M, Żuchowski P, Zwierko B, Wojciechowski R (2017) The role of ultrasonography in monitoring long-standing rheumatoid arthritis: a pilot study. Reumatologia 55:177-182. https://doi.org/10.5114/reum.2017.69781

179. Chang P-Y, Yang C-T, Cheng C-H, Yu K-H (2016) Diagnostic performance of anti-cyclic citrullinated peptide and rheumatoid factor in patients with rheumatoid arthritis. Int J Rheum Dis 19: 880-886. https://doi.org/10.1111/1756-185X.12552

180. Ji L, Deng X, Geng Y, Song Z, Zhang Z (2017) The additional benefit of ultrasonography to 2010 ACR/EULAR classification criteria when diagnosing rheumatoid arthritis in the absence of anti-cyclic citrullinated peptide antibodies. Clin Rheumatol 36: 261-267. https://doi.org/10.1007/s10067-016-3465-9

181. Kwok JSY, Hui KH, Lee TL, Wong W, Lau YL, Wong RWS, Kim DL, Jones BM (2005) Anti-cyclic citrullinated peptide: diagnostic and prognostic values in juvenile idiopathic arthritis and rheumatoid arthritis in a Chinese population. Scand J Rheumatol 34:359 366. https://doi.org/10.1080/03009740510026634

182. Kavanaugh A, Fleischmann RM, Emery P, Kupper H, Redden L, Guerette B, Santra S, Smolen JS (2013) Clinical, functional and radiographic consequences of achieving stable low disease activity and remission with adalimumab plus methotrexate or methotrexate alone in early rheumatoid arthritis: 26-week results from the randomised, controlled OPTIMA study. Ann Rheum Dis 72: 64-71. https://doi.org/10.1136/annrheumdis-2011-201247

183. Kaneko Y, Kato M, Tanaka Y, Inoo M, Kobayashi-Haraoka H, Amano K, Miyata M, Murakawa Y, Yasuoka H, Hirata S, Tanaka E, Miyasaka N, Yamanaka H, Yamamoto K, Takeuchi T, SURPRISE study group (2018) Tocilizumab discontinuation after attaining remission in patients with rheumatoid arthritis who were treated with tocilizumab alone or in combination with methotrexate: results from a prospective randomised controlled study (the second year of the SURPRISE study). Ann Rheum Dis 77:12681275. https://doi.org/10.1136/annrheumdis-2018-213416

Publisher's note Springer Nature remains neutral with regard to jurisdictional claims in published maps and institutional affiliations. 